\title{
Chapter
}

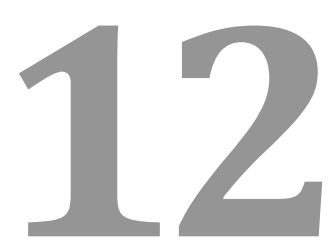

\section{FROM THE MACROSCALE TO}

NANOSTRUCTURES: CAN TISSUE ENGINEERING RECREATE BONE FEATURES?

Nathalie Steimberg ${ }^{1,2 *}$ and Giovanna Mazzoleni ${ }^{1,2}$

${ }^{1}$ Laboratory of Tissue Engineering, Department of Clinical and Experimental Sciences, University of Brescia, viale Europa, 11, I- 25123 Brescia, Italy

${ }^{2}$ Research Center for the Study of Adaptation and Tissue/Organ Regeneration (ARTO), University of Brescia, Brescia, Italy 


\section{Contents}

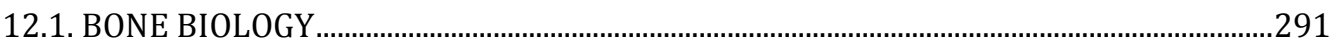

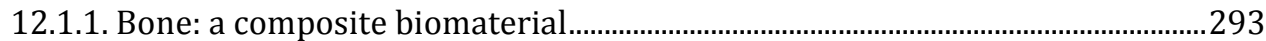

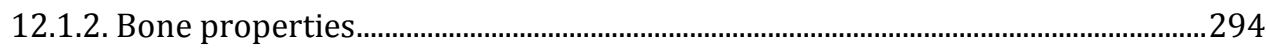

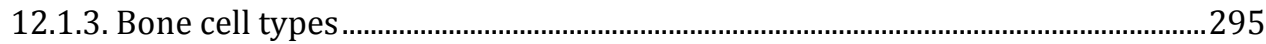

12.1.4. Bone hierarchy, structure and topology ..............................................................29

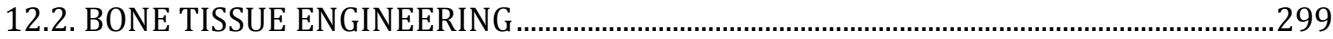

12.2.1. What are the specific requirements of skeletal tissue engineering in vivo and in vitro? ................................................................................................... 302

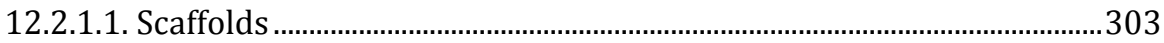

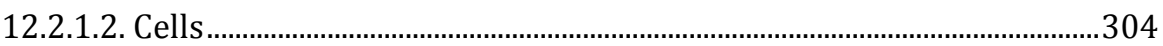

12.2.1.3. Bioreactors applied to bone tissue engineering ....................................305

12.2.1.4. Scaffolds - ECM / microenvironment.........................................................308

12.2.1.5. Scaffold composition ............................................................................. 312

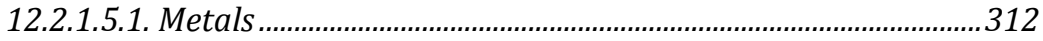

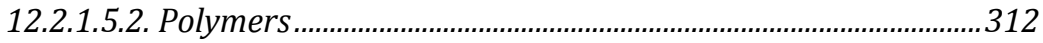

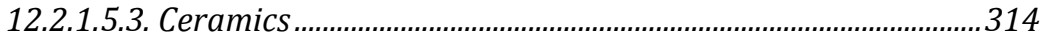

12.2.1.5.4. Biomimetics....................................................................................... 316

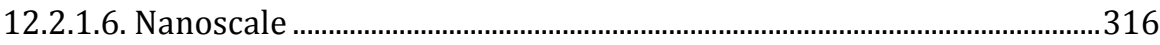

12.2.1.6.1. Nanofibers and nanotubes .......................................................317

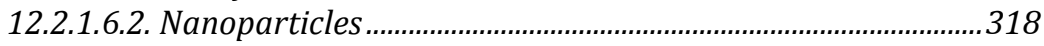

12.2.1.6.3. Nanostructured biomaterials ...................................................318

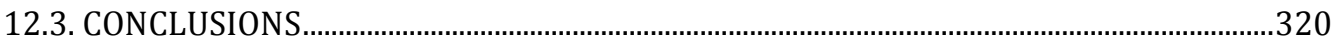

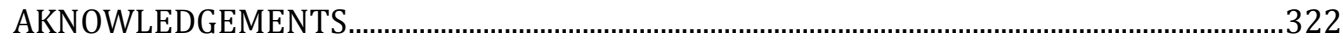

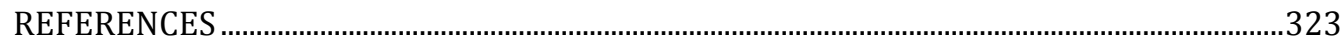




\subsection{BONE BIOLOGY}

Skeleton plays several important roles in the human body: while it houses and protects from injuries critical internal organs and tissues (e.g. brain, heart, lungs, bone marrow and spinal cord), it provides, as well, body mechanical support, movements and locomotion capability. Bones supply insertion sites for ligaments and muscles and, acting as levers, permit, through the joints, the transmission of muscular forces between the different parts of the body. Besides the role of internal framework, human skeleton has also crucial metabolic functions, which include those of mineral storage and maintenance of calcium homeostasis, endocrine regulation of chemical energy (by the release of osteocalcin), acid-base balance, and blood cells production (hematopoiesis processes) that takes place in the bone marrow niche [1].

According to their localization, bones origin from three lineages: the somites, the lateral plate mesoderm, and the cranial neural crest. Bone tissue can be formed following two main pathways, which are represented by intramembranous ossification (for some skull, facial and pelvic bones), or by endochondral ossification (mainly in appendicular and axial skeleton, and in some cranial bones). Whereas both processes embrace mesenchymal precursors as origin of bones, they differ in the characteristics of osteogenesis: during intramembranous ossification, bone progenitors directly differentiate into osteoblasts; on the other hand, during endochondral ossification, mesenchymal cells aggregate, and further differentiate into chondrocytes, up the more differentiated states, called hypertrophied- and post-hypertrophied chondrocytes, that form a mineralized template for the ingrowth of newly differentiated osteoblasts, before dying by apoptosis [2]. Gradually, cartilage/bone become greatly supplied with blood. Bone is, in effect, a highly vascularized tissue, and this aspect is crucial to bear bone development, to maintain bone homeostasis and to support bone repair, since blood and endothelial cells serve as suppliers of nutrient, oxygen, hormones and growth factors, and for the elimination of wastes and of the main toxic end products. Osteoclasts are also recruited from blood precursors in the site of bone formation for remodeling the extracellular matrix (ECM) of the newly synthetized bone into a solid bone matrix. Osteoclasts attach to the bone, dissolve the mineral matrix and, subsequently, the organic matrix, to let free hole for osteoblasts to deposit organic matrix to form osteoid [3-5]. The mineralization of this bone ECM begins several days after osteoblasts have deposited the collagenous matrix. The mineralization process, as well as the osteoblast differentiation, are, at least partially, coordinated by the gap junction-mediated intercellular communication (GJIC), and, more particularly, by the connexin 43 (cx43) component [6]. The biomineralization process is a complex of events that, besides the fine regulation of inorganic phosphate/pyrophosphate balance and the calcium/phosphate supply, is 
controlled by a variety of mechanisms. These mechanisms include: chemical effectors (e.g. ECM, with its proteins, serves as an activator, and as a source / reservoir of growth and differentiating factors, and enzymes cofactors), physical stimuli (e.g. mechanic and electrical forces created by the interactions between cells and cell-matrix), morphological features and structural aspects (cyto-architecture and tissue geometry, known to be involved in the regulation of gene expression), and by the peculiar characteristics of the microenvironment (e.g. proteolytic enzymes, collagen, and matrix vesicles) $[7,8]$. Other important paracrine regulators of bone homeostasis are present in the bone microenvironment, and include bone morphogenetic proteins (BMPs, osteogenic factors), fibroblasts growth factors (FGFs, mitogen and angiogenic factors), insulin like growth factor (IGF, osteogenic factor), Wnt (mitogen and osteogenic factor), Indian hedgehog proteins (Ihh), or hormonal regulators of osteogenesis, such as 1,25 Dihydroxy-vitamin D (anabolic effect and promotion of osteogenic differentiation), parathyroid hormone-related peptide (PTHrP), estrogens (inhibitors of bone resorption), androgens (inhibitors of bone turnover and resorption, and promoters of a subsequent increased in trabecular and cortical bone mass), calcitonin (inhibitor of osteoclasts secretions, and activator of osteoblasts differentiation), growth hormone (GH), and glucocorticoids (activators of bone resorption) [9-12]. Moreover, 1,25-Dihydroxy-vitamin D3 was also shown to stimulate osteoblast for synthesizing vascular endothelial growth factor (VEGF) and, consequently, endothelial cells. Some membrane-associated proteoglycans are supposed to control osteogenesis by interacting as co-receptors with growth factors [13]. In the end, it is important to keep in mind that, in addition to cell-ECM interface, cell-cell interactions are essential for bone formation and maturation. Besides the GJIC, that directly joins two juxtaposed cells and allows the direct exchange of molecular signaling from cytoplasm to cytoplasm, cadherins play a key role in regulating cell condensation, osteogenesis and bone mass [14-17]. Deletion of cx43 in knockout (KO) mice induces a delay in ossification and craniofacial abnormalities [18]. Concerning cadherins, the "block" of $N$-cadherin (by a specific inhibitor or by an antibody) results in the decrease of adherens junctions between osteoblasts, and in a down-regulation of osteoblastic gene expression [19].

Bone is constantly remodeled, in order to better face the daily physical activity, which is often accompanied by "microcracks". To perform such turnover, a basic multicellular unit - comprising bone cells, chemical factors (i.e. growth factors, chemokines, cytokines, systemic hormones), cell adhesion molecules and bone ECM - is essential to allow bone resorption (by osteoclasts), and consecutive bone formation (by osteoblasts). Moreover, the activity of this unit is regulated by numerous local and systemic parameters, such as physical conditions, electric charges and mechanical loads. Also microcapillaries were shown to be involved in the bone remodeling process: they serve either as 
intermediators between the bone marrow and the bone surface to be remodeled, or for recruiting bone cell progenitors in the remodeling site [20]. A delicate equilibrium exists between bone building and bone resorption, but, due to the difference in their kinetics, even a minor imbalance versus resorption can result in dramatic consequences.

\subsubsection{Bone: a composite biomaterial}

Bones are particularly dense connective tissues, where the specific ECM represents about the $92-95 \%$ of the whole mass. Bone ECM consists of two phases: organic (32\% of volume, and about $40 \%$ of bone dry weight) and inorganic ( $43 \%$ of volume, and about $60 \%$ of bone dry weight) $[21,13]$. ECM is responsible for guiding cells behavior by furnishing chemical, physical, and topological instructions. Moreover, aqueous phase is also very important for bone homeostasis, since the loading-unloading cycles induce interstitial flows and pressure gradients [22]. This hydrodynamic flow - and others resulting forces (i.e. matrix/cell strains, shear stress, hydrostatic forces and electrical fields) - regulate the behavior of mechanosensing cells, such as osteocytes, and, furthermore, because of the high mass transfer generated around the cells, they also bring nutrient, hormones, minerals and oxygen to all bone components. Concerning osteocytes, Klein-Nulend and co-workers also hypothesized that this cell type could also sense loading stimuli thanks to its capability to adjust its own morphological configuration, and the distribution of cytoskeletal proteins, according to the mechanical loading pattern it is subjected to $[23,24]$.

The organic components of bone ECM include structural fibrillar proteins, such as collagen (type I collagen represents about the $90 \%$ of the organic part of bone, while type V and type III collagens are present in a few amount), and elastin, that are embedded in an amorphous matrix, made of non-collagenous proteins. The most abundant non-collagenous protein is osteonectin (ONN), a SPARC matricellular protein (SPARC, Secreted Protein Acidic and Rich in Cysteine); important are also fibronectin (FN), thrombospondin, osteocalcin (OCN) and matrix GLA protein, two gamma-carboxyglutamic acid-containing proteins, fibrillin-1 and -2 , alkaline phosphatase (ALP), glycosaminoglycans (GAGs), and proteoglycans (hyaluronan, versican, decorin and biglycan) $[25,7]$. Furthermore, bone ECM also comprises cell surface receptors involved in cell attachment, and integrins, which interact with the Arg-Gly-Asn (RGD) sequence of ECM proteins (type I collagen, thrombospondin, FN, etc.). These interactions between integrins and ECM, play a crucial role in the osteoblastic differentiation process [26]. Osteopontin (OPN) and bone sialoproteins (BSPs) are also involved in the binding of osteoclasts to bone EMC. Collagen orientation and its organization as lamellar material are responsible for bone properties, and for its flexibility and tensile strength, whereas little is known regarding the role of non-collagenous proteins to this concern. ECM proteoglycans are known for their osmotic capacity, that, in response to the 
application of mechanical forces, allow the diffusion of nutrients and gases within bone tissue; the mineralization process extremely decreases this movement of molecules (and cells) [13]. GAGs containing heparin sulfate are, for example, involved in the role of ECM reservoir, since they bind growth factors by non-covalent links.

The inorganic component of bone ECM represents the mineral phase of this tissue, and, mainly, comprises phosphate and carbonate of calcium, crystals of hydroxyapatite (HA), pyrophosphate, di-phosphate and phosphate esters. It also includes other ions, such as magnesium, sodium, fluoride, zinc, manganese, and iron. The inorganic component of ECM contributes to the compressive strength, as well as to the stiffness of bone.

Lamellar bones are made of two different components. The main material is represented by orientated type I collagen fibrils, assembled in well-ordered arrays, and including proteoglycans and non-collagenous proteins. In these arrays, HA is within collagen fibrils. The second material is disordered, and comprises individual collagen fibrils, without ordered-arrangement, proteoglycans, non-collagenous proteins, and an ample ground mass. This more randomly distributed material includes HA crystals inside and outside of the fibrils, and incorporates canaliculi and osteocytes' processes [27].

\subsubsection{Bone properties}

The anisotropic and mechanical properties of bones are related not only to their 3D structure, but also to their composition, and to the arrangement and the linkage between their different molecular components. For example, the mechanical properties of bone change, according to the deposition of apatite / HA crystals [28]; they also depend on bone porosity. The porosity of bones greatly varies according to the site, and to the type of bone: it is comprised between 5-30\% in the compact bone, whereas it is about 30-90\% in the trabecular one [29]. Moreover, bone characteristics can vary from bone to bone (anatomical location), but also within the same bone (bone region), according to age, gender, nutritional state, state of health, calcium availability, sedentary vs. intense physical activities, loading vs. unloading [30]. Finally, bone mass is regulated by leptin, that interacts with its receptor on hypothalamic neurons, and inhibits bone formation (probably by a serotonin-dependent mechanism/s), and should be further mediated by the $\beta 2$ adrenergic receptor [3,31,32]. Ghrelin, known to counteract leptin action, was shown to regulate bone mass by activating osteoblasts and, thus, bone building [33,34].

Mechanical loading is transduced from mechanosensing cells (osteoblasts and osteocytes) into a physiological input, that allows the regulation of bone mass, homeostasis, healing and repair. Focal adhesion kinase (FAK) is believed to be important in mediating mechanotransduction in bone cells, at least when the stimulus arises from shear stress [35]; however, Castillo and co-workers seem 
to indicate that FAK activation could be important only in in vitro systems, rather than in the in vivo situation [36]. Other membrane structures sense mechanical stimuli. They include cell glycocalix, adherens-junctions, integrins, connexins (mainly cx43), and stretch-activated cation channels (L-type voltage-sensitive $\mathrm{Ca}^{2+}$ channels) $[37,38]$. Mechanical loading stimulates bone formation either directly, by activating osteoblasts and inducing their differentiation, or indirectly, after osteocytes' activation [39]. Mechanical loading also induces the synthesis of prostaglandins, ALP and type I collagen. Mechanical strain was shown to play a crucial role in bone homeostasis and repair. In vitro, MC3T3-E1 osteoblastic cells, stimulated by growing tensile strains, increased the mRNA synthesis of osteoprotegerin (OPG), an inhibitor of the osteoclastogenesis, while decreased receptor activator of nuclear factor kappa B ligand (RANKL) expression [40], thus suggesting that mechanical strain can regulate osteoclastogenesis and, at a higher scale, bone modeling / remodeling. The main molecular mediators involved in mechanotransduction are related to nitric oxide (NO), Wnt and prostaglandins pathways. Mechanical stretching and cell tension were also shown as potentially more potent than chemical signals to guide cell behavior and even stem cell commitment $[41,42]$. The mechanotransduction from loading to physiological response of bone, in vivo or in vitro, is regulated at different levels, from cytoskeleton, cell shape and elasticity, and it is also related to the Wnt/ $\beta$-catenin signaling pathway $[43,44]$. In vitro, mechanical stimuli (oscillatory fluid flow) seem to increase osteogenic differentiation of mouse bone marrow (BM)-derived stem cells, at least by epigenic processes (DNA methylation) [45].

Bone stiffness and load-bearing strength are mainly determined by the inorganic components of bone and, more particularly, by the concentration of minerals in the ECM. On the contrary, the organic phase of bone is responsible for the elasticity and flexibility properties of the tissue. The Tensile Strength (TS) is provided by collagen, according to its organization, its orientation, and to the distance between the fibrils; the resistance is also related to matrix organization and collagen cross-links [46]. From the organic matrix, proteoglycans are responsible for the resistance to compressive forces.

\subsubsection{Bone cell types}

Whereas in the bone marrow cells such as fibroblasts, adipocytes, progenitor cells and stem cells can also be found, the typical bone cells are represented by osteoblasts, osteocytes, osteoclasts, and by the resting surface cells. Bone is a dynamic tissue in a permanent renewal and remodeling state. Such a renew / adaptation state is allowed, in normal adult bones, by a delicate coupling between osteoclast-mediated resorption activity and osteoblastmediated bone formation. Bone remodeling depends on mechanical and biological / chemical cues. 
Osteoblasts arise from pluripotent mesenchymal precursors, and are highly specialized cells, involved in bone building. Osteoblastogenesis is under the control of hormones and cytokines (parathyroid hormone, prostaglandins, insulin-like growth factor-1 (IGF-1), transforming growth factor beta (TGF- $\beta$ ), and interleukin 11 (IL11)), as well as under that of Wnt/ $\beta$-catenin pathway, Twist family factors and BMPs [47-49]. Osteoblastic differentiation from precursors is inhibited by the macrophage colony stimulating factor (M-CSF) [50], while runt-related transcription factor 2 (RUNX2) (controlled by the osterix proteins activator of bone formation) represents its main transcriptional up-regulator [51]. Osteoblasts are responsible for the synthesis of bone ECM (type I collagen, fibronectin (FN), ALP, osteopontin (OSP), osteocalcin (OSC), and bone sialoproteins (BSPs)). The regulation of collagen deposition by osteoblasts (orientation, localization, and speed of build-up of fibrils) involves their cytoskeleton, and it is important for the further mineralization of the ECM and, thus, for the mechanical properties of the bone. When ECM becomes mineralized, osteoblasts continue to differentiate and to synthesize ALP and, consecutively, OSC and OSP. By mediating receptor activator of nuclear factor (NF)- $\kappa \mathrm{B}$ ligand (RANKL) and OPN synthesis, osteoblasts play also a fundamental role in regulating osteoclastogenesis [52].

During the elaboration of the new bone, some osteoblasts remain entrapped into the ECM, and terminally differentiate into osteocytes. In vitro, such a differentiation process was shown to depend on the ECM stiffness, and on the distance between the osteoblastic cells (MC3T3-E1 line) [53,54]. Osteocytes are non-proliferating cells, and represent the most abundant cell type of the bone (more than the $90 \%$ of the total number of bone cells). They are embedded in spaces called lacunae, and are interconnected by means of their canalicular systems, forming, therefore, a syncytial network. This organization also allows osteocytes to communicate between themselves, and with the other bone cell types, in part also thanks to the efficiency of the gap junction-mediated communication (GJIC) and to the presence of functional junctional hemichannels [55]. Osteocytes can interplay with other cells by direct cell-cell contact, or, indirectly, by paracrine factors $[56,57]$. They are responsible for the osteoclastic activity during bone repair. Osteocytes are mechanosensing cells: thanks to their long cell processes, they form a network that conducts in the canalicular system the transductive information resulting from loading or other mechanical stimuli (strain detection). To sense biomechanical stimuli, osteocytes processes are anchored to the bone ECM, at least via $\beta 3$ integrins; the interaction between ECM molecules and integrins could then amplify their mechanosensing capacity [58]. It seems that, when osteocytes undergo apoptotic process in response to different physiological events (unloading, estrogen deficiency, fatigue cracks, etc.), neighborhood osteocytes transfer specific signals in order to recruit osteoclasts. Moreover, osteocytes express sclerostin (a Wnt antagonist protein), and, by this way, they can control, in part, bone formation. The shape of both osteocytes and their lacunae influence 
the mechanosensing process, and, then, the correlated processes of bone remodeling and repair [23,59-61].

Osteoclasts are multinucleated cells, derived from hematopoietic stem cells, and resulting (under the control of the macrophage colony-stimulating factor, M-CFS) from the differentiation of the macrophage / monocytes precursor cells at the bone surface. They are responsible for the resorption of bone, performed by acidification and further dissolution of the bone matrix in the "sealing zone", characterized by a particular specialization of the osteoclast membrane [62]. Osteoclasts also secrete proteases (e.g. cathepsin $\mathrm{K}$ and matrix metalloproteinases, MMPs) and tartrate-resistant acid phosphatase (TRAP) that actively disrupt the collagen framework. Osteoclastogenesis depends on different crucial factors. First of all, osteoclasts differentiation cannot occur without their interaction with other bone cells (mainly osteoblasts, and bone marrow or stromal cells) $[7,63,64]$. In addition, the chemotactic recruitment of osteoclasts, and their further development, are supported by several cytokines and hormones, such as interleukines (IL1, IL6, IL11), the receptor RANK (receptor activator of NF-kB factor), the colony stimulating factors-1 (CSF-1), proteins from the tumor necrosis factor superfamily (TNF $\alpha$, RANKL), paratormone $(\mathrm{PTH}), 1,25-(\mathrm{OH})_{2}$-Vitamin $\mathrm{D}$, and calcitonin $[7,65,66]$. RANKL is crucial for the osteoclastogenesis and for the survival and function of osteoclasts [67]. The alternative NF-kB pathway, and, mainly, the p100 component, was also shown to be crucial for osteogenesis [68]. On the other hand, OPG inhibits the activation of the NF-kB pathway. Osteoclasts activity is controlled by PTH, $1,25(\mathrm{OH})_{2}$ vitamin $\mathrm{D}$, calcitonin, cytokines and chemokines [69]. The complex and numerous functions of osteoclasts have been attractively reviewed by Cappariello and co-workers [70], who present in detail the involvement of osteoclasts in bone renewal and in osteoblastogenesis processes, in the regulation of calcemia and phosphatemia, in cooperating with the immune system and regulating angiogenesis, and in maintaining the homeostasis of the hematopoietic niche.

\subsubsection{Bone hierarchy, structure and topology}

Bone acts as a multiscale biocomposite, with a well-organized structure distinguishable at seven different hierarchic levels. These include: I) the macrostructural level $(>1 \mathrm{~cm})$, consisting in the division between cortical and trabecular arrangement of bone structure; II) the mesoscale level $(2-10 \mu \mathrm{m})$, which is represented by the intrinsic lamellae network; III) the micrometer scale level (10-500 $\mu \mathrm{m})$, composed of Haversian systems (or osteons), and single trabeculae; IV) the sub-microscale level $(1-10 \mu \mathrm{m})$, formed by single Haversian canals or single lamellae; V) the nanometer scale level $(<0,1 \mu \mathrm{m})$, comprising collagen fibers and mineral phase; VI) the sub-nanostructural level $(<$ few $\mathrm{nm}$ ), formed by collagen fibrils. The VII) and smallest length scale of the bone hierarchy, consists of the ultrastructural level, and comprises molecular constituents, such as minerals, water, collagen molecules, and non-collagenous 
organic proteins [71-74]. All these structures and components intimately interact altogether in order to give bone its biomechanical properties.

At the macrostructural level, most of bones appear formed by two different structures: the outer one, consisting of compact bone, while the inner one made of cancellous bone, which represent about the $80 \%$ and the $20 \%$ of the skeleton mass, respectively [75]. Bones interface with other bones, muscles, joints, ligaments and tendons. On its outer side, cortical bone is covered by the periosteum (except for the epiphysis region, where it is coated by articular cartilage), whereas in correspondence to the medullar cavity, it is delined by the endosteum. The mature bone is characterized by its lamellar organization. Whereas in the trabecular bone, lamellae do not form an organized structure, in the compact bone lamellae are parallely organized. Trabecular bone is organized as a network of plate-like and rod structures. The microstructure of the trabecular part of the bone is composed of thin trabeculae, made of dense and sinuous lamellae, which form a 3 dimensional complex that holds the bone marrow. Trabecular bone is present, for example, at the epiphyses of long bones. On the other hand, the compact bone is the dense part of bone tissue, and, at the microscale level, it is composed of regular, cylindrically shaped lamellae, arranged around the Haversian canals. Compact bone is mainly localized in the diaphysis of long bones, and blood is mainly supplied throughout the Volkmann's canals. Haversian and Volkmann's canals form a continuous network, where metabolic and gas exchange, as well as waste removal, can take place. The osteon (chief structural unit of compact bone) also includes osteocytes and the network of their relative cell processes. Cortical and trabecular bones are found in almost all bones, but in a ratio that differs according to the site, the localization, and the type of bones. The topics treated in this chapter will be mainly focused on long bones characteristics.

The microscopic level of bone structural hierarchy concerns the biocomposites of type I collagen fibrils / fibers, more or less mineralized. Bone ECM can be classified according to the organization of collagen fibers it is composed of (immature bone, with its unorganized collagen fibers that formed the woven bone; mature bone, composed of collagens organized as concentric lamellae, that formed the osteons of the lamellar bone). Only the mature bone present high resistance properties, due to ECM geometry, organization and composition.

The scale ranging from molecular- to nanometer-sized component, comprises, as already indicated, the molecules of type I collagen, and their associated HA nano-crystals. The conformation, arrangement and deposition of collagen, together with the intra-collagen fiber orderliness of HA minerals, are responsible for the mechanical properties of bones. Concerning apatite crystals, they influence the mechanical properties of bone, according to their shape, their organization, their orientation and their nanometer-scale thickness [76-78]. 


\subsection{BONE TISSUE ENGINEERING}

When bone requires repairing, a complex scenario takes place, including a number of physiological events such as inflammation, healing by endochondral and intramembraneous ossification, and remodeling (Figure 1).

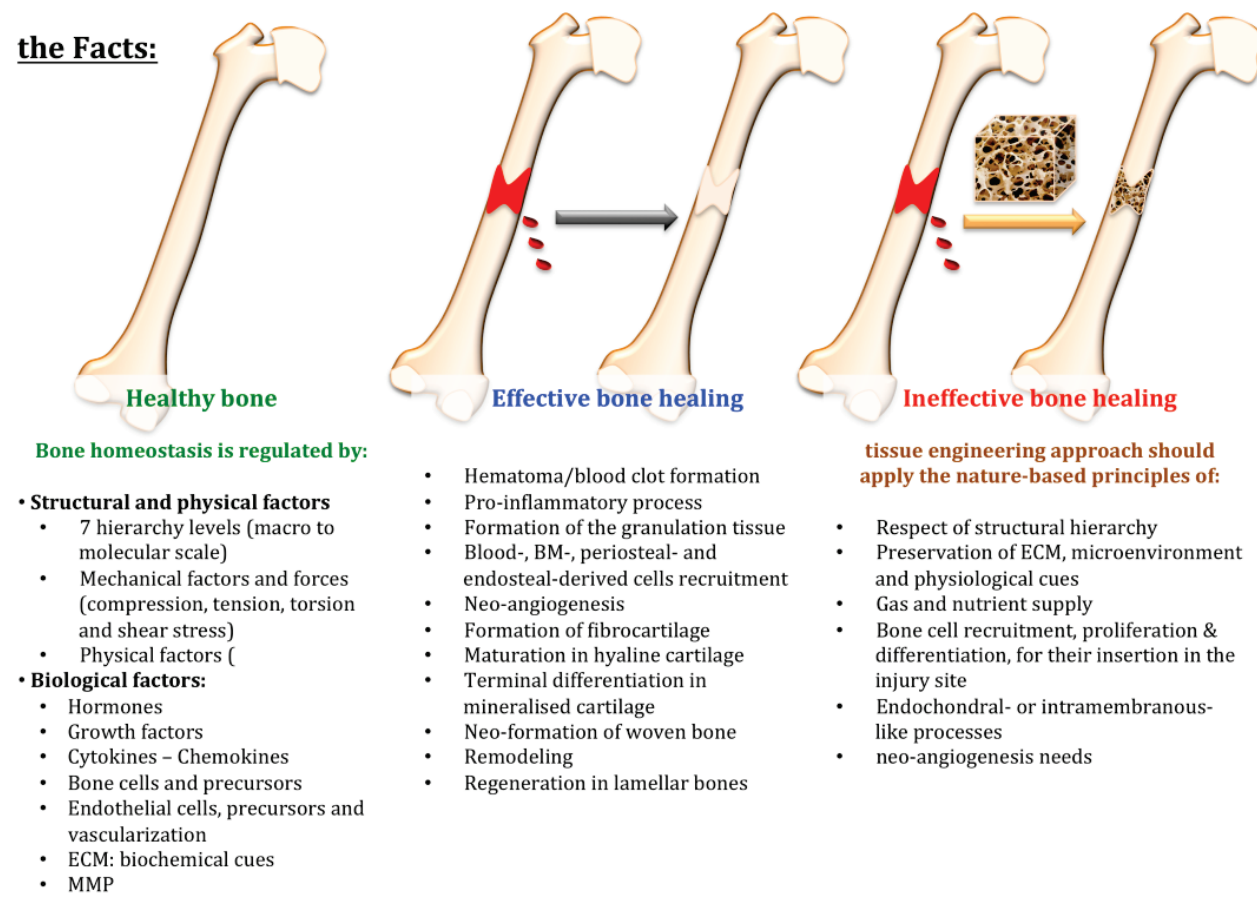

Figure 1. Bone injury, the facts. Healthy bone is characterized by a complex macro-, micro- and nano- environment, where cells, as well as humoral factors, play a crucial role in preserving bone homeostasis. The process of bony healing is complex, and requires a spatio-temporal combination of events to reach an effective bone repair.

When bone is unable to counteract tissue damage, bone tissue engineering could represent an effective therapeutic strategy, if performed by respecting some basal principles.

Bone healing involves a complex microenvironment (Figure 2), composed of a network of cells (osteoblasts, osteoclasts and osteoclasts precursors, endothelial progenitors, lymphocytes, fibroblasts and mesenchymal progenitors, macrophages), growth/differentiating factors, chemokines, cytokines, signaling molecules, mineral elements and ECM macro-, micro-, and nano-components $[79,80]$. Furthermore, this multifactorial process is characterized by an orchestrated succession of events that includes mediators of inflammation, cell chemiotaxis, migration, proliferation, differentiation, 
mechanosensing and tissue remodeling. The existence or the development of adequate blood flow is also essential to sustain full bone development, homeostasis and repair [81,82]. Moreover, the unsuccessful penetration of vasculature into the bone graft also leads to unsatisfactory repair and even bone necrosis. Thus, factors involved in in vivo angiogenesis [VEGF, basic fibroblast growth factor (bFGF), epidermal growth factor (EGF), and angiopoietin-1 (Ang-1)] could be fundamental for supporting bone repair, also in the field of orthopaedic tissue engineering. Endothelial cells can regulate osteoblasts functions by secreting other growth factors, such as endothelin-1 and IGFs [83]. Furthermore, also mechanical stimuli and loading are of crucial importance to improve bone healing.

the Actors:

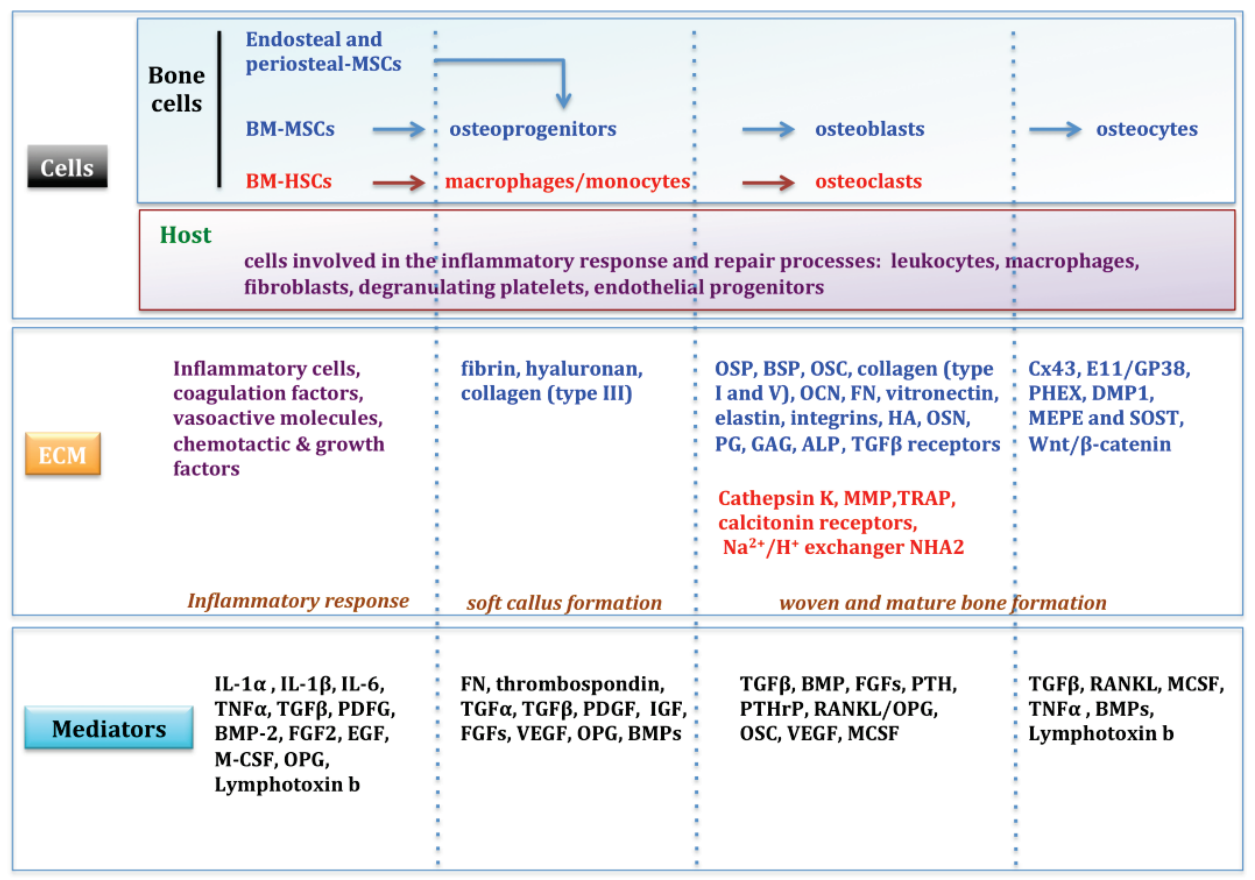

Figure 2. Bone healing, the actors. In order to heal, bone needs strict crosstalks between all the actors of the skeletal micro-environmental network. Cells (stem or mature cells), ECM (with its soluble and insoluble components), and mediators (autocrine, paracrine or humoral chemical signals) are the main actors of bone healing, and their specificity (and intervention timing) must be recognized, in order to optimize the efficacy of tissue engineering-based treatments.

Even if the more traditional treatment of bone defects is, first, represented by the autologous graft and, secondly, by bone allograft or distraction osteogenesis, several drawbacks can be encountered. These include, for 
example, the insufficient size of bone to be grafted (as in the case of large bone defects due to tumor resection, trauma or infection), or when the host site of injury is altered by avascular necrosis, or by a pronounced osteoporosis. Other obstacles arise when blood and cell supply in the wound-healing site is too scarce, if the osteointegration is incomplete, in the case of donor site morbidity, or in the presence of an adverse immune response. To overcome such limits, the tissue-engineering field offers the possibility to amplify cells number in vitro, and, successively, to use them in order to generate a tissue substitute, ultimately disposable for graft. Alternatively, acellular scaffolds can be directly implanted in the site of injury, awaiting its colonization by host cells. As for scaffolds carrying living cells before they are implanted into bone defects, also these acellular scaffolds can be manufactured by demineralized matrix [84], natural or synthetic polymers, biocomposites, ceramics, and, often, they need to be functionalized in order to optimize local cell ingrowth, proliferation and differentiation (Figure 3).

\section{the Scenarios:}

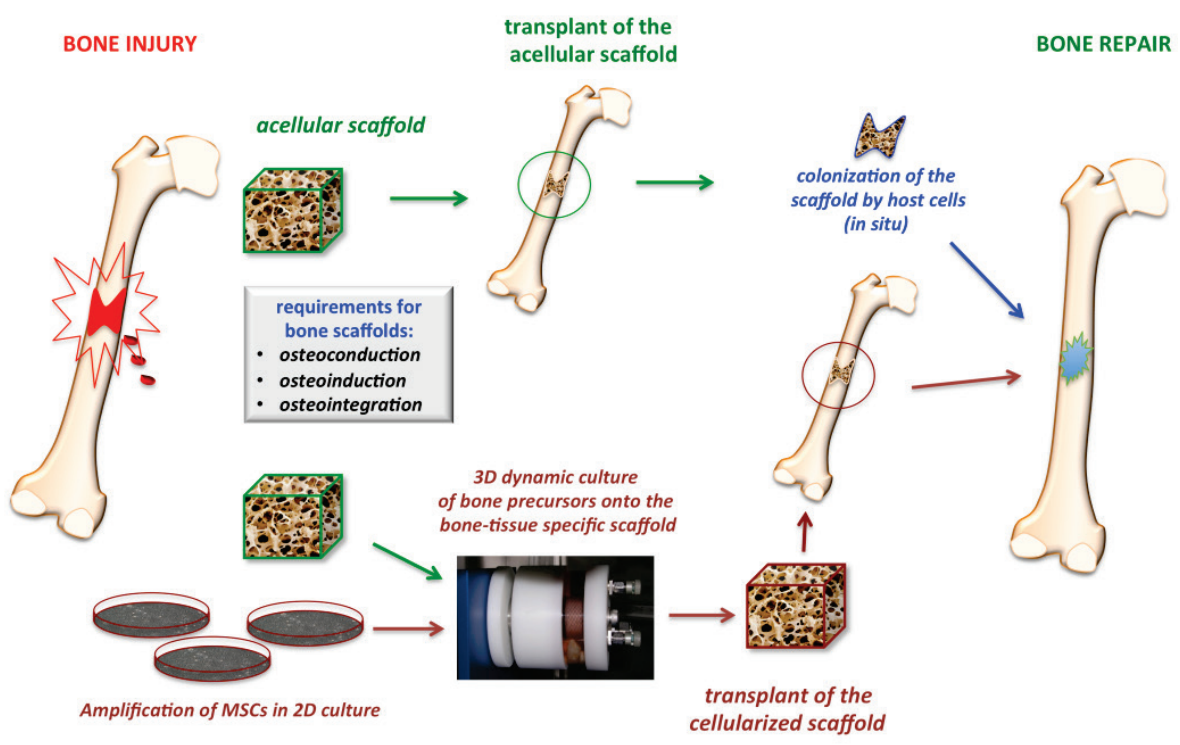

Figure 3. Tissue engineering-based orthopedics strategies. If a scaffold is used, orthopedics can also choose to introduce (and model) a scaffold, free of cells, in the site of bone injury. Bone repair should be observed after the colonization of this scaffold by

local cells and precursors. Alternatively, bone cell precursors/stem cells can be amplified in vitro, guided to colonize the scaffold (3D culture gives better results) and, finally, the cellularized scaffold can be implanted in the site of injury. These processes can be supported by a supplement of specific chemical mediators, previously enclosed in the scaffold ("functionalized" scaffold). 


\subsubsection{What are the specific requirements of skeletal tissue engineering in vivo and in vitro?}

Tissue engineering is intended for developing tissue substitutes, able to restore, maintain and / or increase tissue functions in vivo [85]. To reach this objective, two main key factors should be taken into account: i) the scaffold, that will serve as physical support, and as supplier of molecular factors able to induce cell proliferation and/or to guide cells into specific lineages of differentiation, and ii) the cells, that must invade the scaffold and produce the neo-tissue. For the in vitro development of engineered tissue, a bioreactor, able to support neo-tissue formation and growth, is also necessary. The scaffolds produced by tissue engineering for regenerative medicine aims, must be, obviously, biocompatible and sterilizable, in order to avoid any induction of inflammatory and / or immune response. Concerning, bone tissue engineering, the main crucial points are summarized in Figure 4.

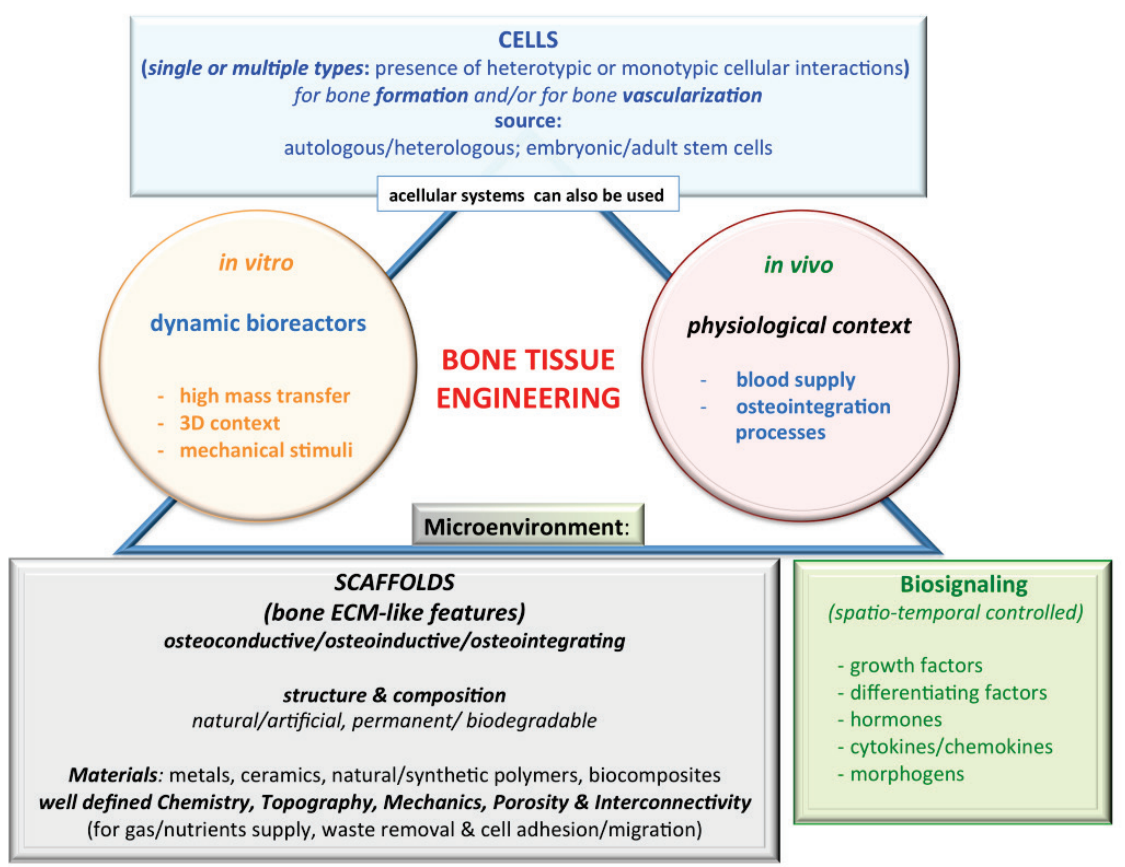

Figure 4. Bone tissue engineering: an example of translation medicine from bedside to bench prior the return to the boosted bedside part. As shown in Figures 1 \& 2, bone healing involves number of actors, and all of them need to be taken into account during the whole tissue engineering procedure to better mimic the in vivo conditions. Thus,

regarding bone engineering, the main parameters, that must be finely defined to reproduce as much as possible the in vivo situation, are the cells (origins, their history, their commitment etc.), the bioreactors, the optimal microenvironment (where osteoconduction, osteoinduction, osteointegration properties of the scaffold are promoted by the induction of the optimal biosignalling pathways, and the reproduction of the native bone physical, chemical, topographical and biological cues). 
They include the interaction of cells, usually precursors of bone tissue or endothelium, with an adequate microenvironment. This last comprises a scaffold, harboring various chemical, physical, and mechanical properties, as well as bioactive molecules, involved in the recruitment and differentiation of cells (in the scaffold and/or in the site of implantation). Lastly, particular growth and angiogenic factors can be used, in order to recruit endothelial cells, and to further favor bone formation and survival, since nutrient and gas supply can be performed by diffusion processes only up to a tract of $200 \mu \mathrm{m}$ [86-88].

\subsubsection{Scaffolds}

The ideal scaffold for bone tissue engineering should mimic the native macroscopic bone organization, as well as the bone microenvironment and features, since these conditions allow the natural cell recruitment, adhesion, migration, proliferation and differentiation. As already mentioned above, bone cells' behavior is finely regulated by ECM properties (biochemical, physical, geometrical, and topographical aspects). The surface of biomaterials must, then, possess well-defined characteristics, since substrate chemistry, tension and topography play a fundamental role in regulating cell behavior and bone tissue features $[89,90]$. The perfect scaffold (Figure 5) usable for bone tissue engineering, has, in addition, to possess mechanical properties close to those of the in vivo tissue, shall recapitulate its 3D architecture, must favor cell adhesion / attachment, osteoconduction (related to the capacity of biomaterial surface to allow cell growth), osteoinduction (related to the capacity of biomaterials to guide stem and bone precursor cells toward the osteogenic pathway of differentiation), and cell functions [91]. Osteoconduction, osteoinduction and the further peri-bioengineered-implant healing, as well as osseointegration, are fundamental for regenerative orthopaedic procedures. Along with the 3D organization, it is necessary to take into account also the need of specific bone growth factors, which, in addition, must be released gradually, according to a well-defined spatio-temporal schema. Moreover, because of the need of nutrients and gas supply, a scaffold favoring an early angiogenesis in the neo-tissue is desirable. In effect, co-cultures of osteoblasts (or osteoblastic precursors) with endothelial cells (or endothelials precursors) have been shown to favor cell communication mediated by gap junctions (GJIC) between these cell types, and to support osteoblastic differentiation [92 93]. Kim and co-workers [94] confirmed this support for bone formation after the seeding of adipose-derived MSCs and human umbelical vein endothelial cells (HUVEC) in solid free form-based poly( $\varepsilon$-caprolactone)(PCL) / poly(lactic-co-glycolic acid) (PLGA)/tricalcium phosphate (TCP) scaffolds. After 8 and 12 weeks of implantation in a rat calvaria defect, the implants with co-seeded cells reinforce osteogenesis, bone-like formation, and mineral deposition, as compared to monotypic (osteoblasts-only) seeded scaffolds. 


\section{the Context:}

\begin{tabular}{|c|c|c|c|c|c|}
\hline $\begin{array}{l}\text { NATURAL } \\
\text { BONE }\end{array}$ & BIOMATERIALS & MAIN PROPERTIES & $\begin{array}{l}\text { OPTIMISATION } \\
\text { FOR BONE TISSUE } \\
\text { ENGINEERING }\end{array}$ & TOPOGRAPHY & CHEMISTRY \\
\hline & $\begin{array}{l}\text { Natural 3D } \\
\text { biocomposite } \\
\text { scaffold } \\
\text { organic and } \\
\text { inorganic ECM } \\
\text { components }\end{array}$ & $\begin{array}{l}\text { - porosity (cortical } \\
\text { bone: low; } \\
\text { trabecullar bone: } \\
\text { high) } \\
\text { - interconnectivity } \\
\text { - modeling/ } \\
\text { remodeling } \\
\text { - mechanics }\end{array}$ & $\begin{array}{l}\text { PRP or growth/ } \\
\text { differentiating } \\
\text { factors spatio- } \\
\text { temporally supplied } \\
\text { with nano-vehicles }\end{array}$ & $\begin{array}{l}\text { - naturally rough, } \\
\text { due to the } \\
\text { molecular } \\
\text { association of } \\
\text { ECM components } \\
\text { - presence of } \\
\text { whole-scale length } \\
\text { (macro-, meso-, } \\
\text { micro-, nano-) } \\
\text { andcorrect } \\
\text { molecular } \\
\text { arrangement }\end{array}$ & $\begin{array}{c}\text { ECM naturally } \\
\text { contains adhesive, } \\
\text { chemioattractive, } \\
\text { growth-stimulating, } \\
\text { and } \\
\text { differentiating } \\
\text { factors }\end{array}$ \\
\hline $\begin{array}{l}\text { ARTIFICIAL } \\
\text { SCAFFOLD }\end{array}$ & BIOMATERIALS & MAIN PROPERTIES & $\begin{array}{l}\text { OPTIMISATION } \\
\text { FOR BONE TISSUE } \\
\text { ENGINEERING }\end{array}$ & TOPOGRAPHY & CHEMISTRY \\
\hline 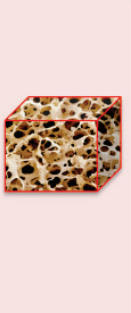 & $\begin{array}{l}\cdot \text { metals } \\
\cdot \text { ceramics } \\
\text { - bioglasses } \\
\text { - natural polymers } \\
\text { - synthetic polymers } \\
\text { - biomimetic } \\
\text { materials }\end{array}$ & $\begin{array}{l}\text { - porosity (macro-/ } \\
\text { micro-scale) } \\
\text { • interconnectivity and } \\
\text { open pores } \\
\text { - biodegradability and } \\
\text { harmless of by } \\
\text { products } \\
\text { - mechanical } \\
\text { properties }\end{array}$ & $\begin{array}{l}\text { - biocomposites } \\
\text { - surface coating } \\
\text { - spatio-temporally } \\
\text { release of growth/ } \\
\text { differentiating } \\
\text { factors }\end{array}$ & $\begin{array}{l}\text { - doughness (micro- } \\
\text { and nano- scale) } \\
\text { - discontinous }\end{array}$ & $\begin{array}{l}\text { adsorption of } \\
\text { molecules (or } \\
\text { proteins/DNA/ } \\
\text { miRNA sequences) to } \\
\text { increase cell } \\
\text { adhesion- } \\
\text { osteoconduction (FN, } \\
\text { laminin, collagens, } \\
\text { hyaluran, heparin, } \\
\text { poly-lysine, etc.) and } \\
\text { osteoinduction } \\
\text { (rhBMPs, etc.) }\end{array}$ \\
\hline
\end{tabular}

Figure 5. How is reproduced the in vivo skeleton context in tissue engineering and scaffolding? Number of parameters are now well-known for their fundamental role in regulating bone repair. Concerning the development of scaffold usable in orthopedics, a lot of biomaterials, based on native bone properties, have been created and modified

to reach a better level of osteointegration, osteoconduction and osteoinduction.

The properties of engineered tissue requirements (mainly strength) vary because not all bones have to support the same loading forces, and, then, different scaffolds may be used. So, it demands considering a wide range of biomaterials as suitable ones.

\subsubsection{Cells}

The need of reliable source of cells is important. The main, fundamental property of these cells should be the absence of immune response induction. Thus, the best way to avoid any adverse immunizing capacity, is to use cells from autologous donors. Since osteoblasts are very difficult to isolate and, further, to amplify in vitro, the best choice is the use of adult stem cells, or osteoprogenitors able to differentiate versus the osteoblastic phenotype.

The multipotency of adult stem cells and their high capacity to proliferate render their use very promising for engineering bone. Another advantage of adult stem cells is that, bone marrow-derived stem cells, as placenta's one, for example, present an immunomodulator effect, that renders them attractive 
also for allo-transplants [95-97]. Adipose-, umbilical cord- or placenta-derived stem cells represent an easy-to-use source of cells, as compared to bone marrow-derived cells [98]. But, even if almost all mesenchymal stem cells (MSCs) are able to differentiate into different lineages, not all the sources of MSCs present the same plasticity to follow the osteoblastic lineage up to the terminally differentiated phenotype [99]. Endothelial progenitor cells (EPCs) were also used for bone healing, and a synergic effect was observed when both MSCs and EPCs were co-seeded with $\beta$-TCP granules [100]. Endothelial progenitor $\mathrm{CD}_{34}{ }^{+}$population was also directly injected in a rat bone fracture site. Both neo-angiogenesis and osteogenesis were activated and resulted in bone healing [101]. The co-culture of MSCs and monocytes was shown to favor MSCs differentiation toward osteoblastic lineage, against adipocyte lineage. Moreover, osteoblasts downregulated the number of osteoclast-like cells, so mimicking the fine equilibrium between these two cell types, and suggesting that also osteoclast precursors could play an important role in developing bone neo-tissue [102]. Another strategy should be the recruitment of host endothelial progenitors (or mature cells), as well as of native MSCs, into a scaffold, serving as bioactive molecules carrier, and as temporary template and structural support for bone formation.

For exploiting engineered bone tissue as ex vivo model to perform studies on bone physiopathology or pharmacotoxicology, cell lines can be used instead of stem cells. The available cell lines are numerous, and each of them possesses individual properties. The most known cell lines are: the UMR106, the MC3T3-E1 and the MG-63 cells for the pre-osteoblastic and the osteoblastic lineages; the MLO-Y4 cells and the FLG 29.1 cells for the osteocytic and for the osteoclastic lineage, respectively. Moreover, there is a growing interest concerning human-induced pluripotent stem cells; these reprogrammed cells can differentiate into many cell lineages, comprising bony lineage, but their use for human implants still need further investigation [103].

\subsubsection{Bioreactors applied to bone tissue engineering}

Bioreactors are devices able to reproduce/maintain a tissue-like microenvironment, and to provide controlled culture conditions (e.g. temperature, $\mathrm{pH}, \mathrm{O}_{2} / \mathrm{CO}_{2}$ and nutrients supply, flow rate, chemical/mechanical stimuli, etc.). Bioreactors need to favor mass transfer (nutrient and gas supply + waste removal), without exposing cells to high shear stress forces, that may be risky for their function and survival. This high-mass transfer/low-shear stress operational regimen can be attained by devices able to generate fluid-dynamic culture conditions (an interesting review, published by Rhiel and Lim, illustrates the importance of macro- and micro-fluidic flows on bone tissue formation, describing also the importance of the flow dimensionality on regulating cell / tissue behavior) [104]. Moreover, bioreactors usually furnish the possibility to maintain or recreate the three-dimension (3D) microenvironment generally present within a tissue. This 
dimensionality is also important, because it allows the establishment of interactions between cells and ECM, which are very different from those created in the classical, static 2D culture condition. In such 3D conditions, cells sense each other, receive / exchange biochemical and biophysical cues from ECM, adapt their behavior, and, in turn, can change ECM properties. This is of great importance when mechanosensing cells or bone tissues must be studied. At last, the highly controlled fluid-dynamic conditions reached within specific bioreactors are necessary to improve cell seeding, proliferation, migration, and their further differentiation onto / into the scaffolds.

Rotating wall vessels. One example of fluid-dynamic bioreactors are the rotary cell culture system (RCCSTM) devices, developed by the N.A.S.A.'s Johnson Space Center technological research (Synthecon Inc., U.S.A.). These bioreactors are composed of a horizontally rotating culture vessel, which angular speed can be regulated in order to reach optimal hydrodynamic conditions for cell / tissue culturing or, alternatively, to reach a peculiar equilibrium between the main forces acting on the cells (gravitational, centrifugal and fluid drag forces), that simulates some features of microgravity [105-107]. The vessel is fully filled with culture medium, avoiding the presence of air bubbles and, thus, deleterious turbulent forces. Therefore, this bioreactor can effectively provide cultured cells with a low-shear stress and a high-mass transfer microenvironment. In such a 3D hydrodynamic culture conditions, isolated cells or tissues explants remain alive, and express their tissue-specific phenotype from several days up to weeks of culture [106,108-112]. The RCCSTM bioreactor was also successfully applied, also by our group, to the study of the skeletal system on isolated cells, in the presence or in the absence of scaffolds, or on bone explants [107,113-117]. This bioreactor was also shown to speed up cell aggregation, osteoblastogenesis, osteoblast differentiation, and subsequent mineralization of mesenchymal or embryonic stem cells [109,115]. Goldstein and co-workers [118], contrariwise, demonstrated that, when seeded on PLGA scaffolds, rat osteoblastic cells better differentiated if kept in spinner flasks or in perfusion bioreactor, rather than in the RCCS ${ }^{\mathrm{TM}}$ device. According to our experience, it is possible that the results obtained by Goldstein's group were due to the specificity of the scaffold they used (i.e. density, surface conformation, size, interaction with fluid flow and relative deleterious forces). Even if not always easy to use for growing large engineered tissue masses, Hidaka and co-workers succeeded in transplanting RCCS ${ }^{\mathrm{TM}}$-engineered bone tissue in a rat calvarial bone defect, since this neo-tissue was further replaced by a mature bone after 2 months [119]. Song and co-workers [120] performed a comparative study between static conditions (T-Flasks), and dynamic conditions (spinner flasks and RCCS $^{\mathrm{TM}}$ bioreactors). They showed that the osteoblasts seeded within an acellular bone-derived scaffold could reach a better state of differentiation when maintained in the RCCSTM device. Another example of rotating vessel is the BIOSTATS ${ }^{\circledR}$ Bplus RBS bioreactor, a cylindrical rotating bed system, which 
allows the seeding of the MC3T3-E1 pre-osteoblastic cell line onto a ceramic carrier (Sponceram ${ }^{\circledR}$ ). These conditions were more effective than the static ones, and, after several days of culture, cell proliferated and further differentiated, expressing OCN and type I collagen, and depositating mineralized matrix [121,122].

Perfusion bioreactors. They are basically organized as one or more culture chambers coupled up to tubing circuits and culture medium reservoirs. The whole system forms a closed circuit media loop, regulated by a peristaltic pump. This last allows perfusing cells dynamically, even when grown into a scaffold. As compared to the RCCS ${ }^{\mathrm{TM}}$ bioreactor, the regulation of fluid flow is finer in classical perfusion bioreactors; however, it also exists a Perfused RCCS $^{\mathrm{TM}}$ device, in which the laminar flow created by the rotation of the vessel and culture medium is almost unaffected by the perfusion process.

The perfusion bioreactors, in their several versions, recapitulate, at least in part, the potential interstitial fluid flow. As in vivo, flow characteristics depend on scaffold properties (structure, porosity and interconnectivity). There are different types of perfused bioreactors. In a perfused chamber, the MC3T3-E1 osteoblastic cell line was exposed to a fluid shear of $1 \mathrm{dyn} \mathrm{cm}^{-2}, 12 \mathrm{dyn} \mathrm{cm}^{-2}$ or $25 \mathrm{dyn} \mathrm{cm}^{-2}$. In these conditions Ryder and Duncan [123] observed a magnitude-dependent increase in the intracellular concentration of calcium; this effect was significantly higher when the cells were stimulated with PTH, suggesting that cell response induced by shear and PTH is mediated by the modulation of mechanosensitive cation-selective channels, and L-type voltage-sensitive channels. The culture of rat BM-MSCs in perfused bioreactors without the addiction of dexamethasone (a supplement usually employed to induce stem cell differentiation in osteoblasts), was shown to allow the differentiation of cells in the osteoblastic lineage; in the presence of both perfusion and dexamethasone, the differentiative process was enhanced [124]. Oscillatory perfusion was shown to be more efficient in engineering bone from MC 3T3-E1 osteoblastic-like cells seeded on porous ceramic, than the conditions generated by unidirectional or static bioreactors $[125,126]$.

Spinner flasks. These bioreactors produce a dynamic flow, due to the mixing of medium by a stirring element localized at the bottom of the tank, whereas scaffolds are usually anchored to a needle, connected to the cap of the flask. These bioreactors are more difficult for monitoring hydrodynamic flow. Thus, turbulent forces and shear stress could be created, inducing cell sufferance. In such a bioreactor the Saos-2 osteoblastic cell line was shown to attach to HA-incorporating microcarriers and proliferate in a more efficient way than when the microcarriers were kept in static conditions [127]. Seeded into a decellularized bone-derived scaffold, adipose tissue-derived stem cells are able to adhere, migrate, grow and differentiate into osteoblastic cells expressing ALP. In these 3D hydrodynamic culture conditions, the level of differentiation was higher than in static conditions $[128,129]$. However, Rat BM-derived MSCs 
better differentiated when maintained in a perfused system, rather than in spinner flasks [130].

Applying an adequate biomechanical stimulus, in order to better recapitulate the dynamic bone activities, is also of importance in in vitro, as well as in in vivo conditions. Usually, in vitro, the main mechanical strains that are reproduced are compression, stretching, contraction, and bending. Cyclic compression and cell perfusion enhanced BM-derived MSCs commitment and cell proliferation into a decellularised ECM scaffold, respectively [131]. BM-derived MSCs were shown to positively respond to these two stimuli by increasing collagen synthesis, also with polyurethane scaffolds. However, whereas the initial tensile modulus was elevated, it drastically decreased after two weeks of culture [132]. Contrariwise, Sittichockechaiwut and co-workers [133] showed that, as compared to unloaded cells, the MLO-5 osteoblastic-like cells were able to increase bone matrix synthesis (collagens, mineralization, OPN and OCN) when kept into a polyurethane scaffold and exposed to cyclic compressive stimuli. Moreover, with time, the samples acquired a higher stiffness. Elongation strains were also applied to MSCs, with or without dexamethasone [41]. Cyclical stretching together with dexamethasone favored osteogenic commitment of BM-derived MSCs, whereas mechanical stimulation alone significantly stimulated cell differentiation (increase in ALP levels and in collagen and OCN synthesis). The results confirmed that the mechanical stimulus could be as effective as the chemical one to induce bone cell differentiation [134]. Akhouayri and co-workers [135] evaluated the effect of contractive forces onto ROS 17/2.8 osteosarcoma-derived cells. Different contractile conditions were reached in type I collagen gels (freely retracted gels, stretching of the tense gel, periodic stress). The results showed that cell response (proliferation, morphology, ALP activity, OCN secretion, and ECM mineralization) depends on the attributes of the contractile stimulus. Static and dynamic mechanical forces differentially regulate cell behavior and phenotype. As an example, the osteoblastic differentiation induced by contractile collagen gels is mediated by the MMP-2/MMP-13/MT1-MMP cascade of metalloprotases [136], while a bending stimulus, tested on BM-derived MSCs seeded in biomimetic material, is able to upregulate osteogenic differentiation in the presence of dexamethasone [137].

\subsubsection{Scaffolds - ECM / microenvironment}

Biomaterials can be prepared as fillers for injection in injured sites, or as scaffolds for cell repopulation procedures. Whereas scaffolds were initially developed to sustain cell viability, technical progresses have allowed the development of more dynamic scaffolds, whose properties can be regulated to guide cell behavior (in vitro and in vivo), and to sustain the further osseointegration process. As already known, in vivo, cells are embedded in a 3D-organized ECM, the roles of which are to support cell adhesion, to promote cell organization, polarization and growth, to guide cell migration, to favor 
nutrients' diffusion up to all bone cells, to provide growth factors and serve as mineral reservoir, and to be responsible for the structural and mechanical properties of the tissue. In vivo, the ECM is fundamental for the chemical, physical and topographical cues that provide to bone cells. Scaffolds designed for bone tissue engineering should then recapitulate such signals and properties and, consequently, in their conception, the following characteristics should be considered.

Porosity and connectivity. Scaffolds need to present open cavities (pores) to favour cell adhesion and proliferation. Bone cells are sensitive to the gross morphology of scaffolds. For osteoblasts, the suitable size of pores was shown to range between $100-400 \mu \mathrm{m}$ in diameter. According to the cell type, the interconnectivity of these pores or / and additional micropores (important for an efficient mass transport), can promote homogeneous cell repartition, nutrients supply, and metabolic waste removal. Moreover, a pore diameter greater than $100 \mu \mathrm{m}$ was shown to favor blood vessel ingrowth [138]. For a bone tissue analogous, the highly porous structure also better mimics the natural 3D architecture of the tissue.

Biodegradability or permanency. According to the aim to be attained, the scaffold can be either bioresorbable or permanent. The scaffold should, in effect, temporary behave as a template, allowing the ingrowth of bone cells, the expression of specific cell functions, the growth of neo-formed bone tissue and, eventually, the ingrowth of vascular components. When implanted in bone defects, it is of importance to finely regulate the degradation rate of the scaffold, in order to obtain a complete substitution of the biomaterial by the newly formed bone, and to avoid its collapse. The development of new biodegradable materials requires also to think about the byproducts of their degradation, since these last can induce a change in the graft microenvironment, and, as consequence, hinder transplant osteointegration and / or bone formation [139].

Mechanical properties. One of the major problems encountered for developing scaffolds suitable to be used in bone tissue engineering is to find the just balance between a scaffold harboring a high porosity, and the necessity that it can also maintain, at the same time, high stability, stiffness, strength, and toughness properties. Whereas for the in vitro studies engineered bone can present less strength capacities, for the in vivo use the engineered tissue must be able to face the natural mechanical forces experienced during the daily activity of the body (load, torsion, compression, etc.). The more the bone defect is wide, the more the biomaterials must be mechanically stable, and it is more so true if a biodegradable scaffold is used. Another strategy to increase the mechanical features of the bone micro-environment, is to use a calcium channel agonist, that favours bone formation.

Surface roughness was, as well, shown to influence cell behavior $[140,141]$. Even if both amplitude and organization characteristic of roughness variation 
in surface texture or microtopography can affect the cellular response to an implant, it seems that the organization plays a more important role [142]. When examining the ability of osteoblast-like cell to attach to titanium surfaces, it was found that a higher percentage of cells attached to the rougher surface [143,144]. However, it remains difficult to strictly monitor cell behavior and, since experimental conditions vary from lab-to-lab, the significance of roughness effect on bone cell homeostasis is not always evident.

Surface tailoring. As for a number of other cell types, either the (bio)chemical or the physical (topographical) properties of the scaffold surface can modulate and guide bone cell behavior [145]. Functionalization of the scaffold surface allows regulating adhesion and migration of cells onto the scaffold (osteoconduction), as well as stem or progenitor cells differentiation (osteoinduction).

Combination of scaffolds with soluble and bioactive molecules was shown to control bone cell behavior. In order to increase osteogenic properties of the scaffold, it may be integrated with osteoinductive growth factors and morphogens, which provide physiological regulation of bone features (e.g. TGF- $\beta$, BMPs, VEGF), or with drugs / polymeric carriers, used for gene delivery. To drive cell performance in order to optimize bone repair, different growth factors were tested in humans. The main bioactive molecules, which demonstrated to be effectively able to improve bone healing, are some members of the TGF- $\beta$ superfamily of proteins (BMPs, TGF- $\beta 1$, TGF- $\beta 3$ ), members of the parathyroid hormone family (PTH, PTHrP), and plateletderived growth factor (PDGF). However, many bioactive molecules were tested in vivo (on animals) or in vitro. In addition to the precedent ones, they include IGF, bFGF and the Wht signaling proteins. BMPs (the most osteoinductive proteins are BMP $2,4,6,7$ ), TGF- $\beta$, FGF, IGF-I/-II, and PDGF are the most commonly used bioactive molecules employed in bone tissue engineering [146]. BMPs represent fundamental proteins, and are directly involved in the whole osteogenesis process. The key role of one of them, BMP-7, was demonstrated by the transdifferentiation of BMP-7 transduced fibroblasts into osteoblasts [147]. Carriers usually associated for bioactive molecules delivery are often polymer-based biomaterials. Natural carriers that can be, for example, used to this aim, are collagen and hyaluran; among synthetic polymers, poly(lactic acid) (PLA), poly(glycolic acid) (PGA) and poly(lactic-co-glycolic acid) (PGLA) are the most widely used. Recombinant human bone morphogenetic protein-7 (rhBMP-7) was also demonstrated to be able to induce cell proliferation and osteoblastic differentiation [148]. Dadsetan and co-workers [149] recently proved that the coating of poly(propylene fumarate) scaffolds with carbonated HA and rhBMP-2 results, after 6 weeks of implantation in calvaria defect, in a significant increase in bone formation, and in an effective osseointegration. These findings suggest that rhBMP-2 and HA, added together, could represent a good strategy to repair large bone defect. Zhang and co-workers [150] also demonstrated that rhBPM-2 loaded calcium 
silicate / calcium phosphate cement stimulate cell adhesion to the scaffold, osteogenesis and bone repair, with a higher efficiency, as compared to either the cements alone, or the growth factor alone. These results confirm that bioactive molecules are necessary to furnish biological cues to cells, but the macro- and micro-porous arrangement of the scaffold is fundamental, as well. Moreover, as for healthy bone, where the mechanical properties result from the synergic effect of the whole component of bone tissue, in this particular case, the effect resulting from the combination of cement-based biomaterial and growth factor is higher than that of the single components. Another strategy that is currently of a great interest in tissue repair and tissue engineering strategies is the use of platelet-rich plasma (PRP). This preparation is rich in the growth factors that are commonly involved in bone formation and homeostasis in vivo, as, for example, TGF- $\beta 1$, bFGF, PDGF, IGF-1, EGF, VEGF, Factor V, Factor XI, Factor XIII, fibrinogen and von Willebrand factor (vWF), OSC, FN and Angiotensin-2 (Ang-2) [151,152]. Nevertheless, the results obtained with PRP are still controversial, probably due to the difference in PRP preparation between the different laboratories. Clinical trials are necessary to ascertain the most efficient PRP preparation protocol, and its real effect on bone healing process. For mimicking cell adhesion mediated by integrins, RGD sequences can also be incorporated into biomaterials. HA bio-functionalised with peptides harboring the RGD sequences allows a better adhesion of osteoprogenitors [153]. The adsorption of bioadhesive molecules, such as FN or laminin, could also enhance the interaction cell-scaffold [154]. Another interesting strategy, developed by Yang and collaborators [155] and by Wood and collaborators [156], is based on the use of a voltage-operated calcium channels agonist, delivered to mouse MG63 or rat ROS 17/2.8 cells exposed to a mechanical stimulus by a poly(L-lactic acid) (PLLA) scaffold. The results obtained showed that this scaffold modulates the mechanosensitivity of mouse osteoblasts, and increases cell differentiation (type I collagen and ALP production), as compared to the osteoblasts that received only the mechanical stimulus. Moreover, the PLLA porous biomaterial allowed a long-term release of the agonist, since it was stable over the 28 days culture period. Lastly, in addition to DNA delivery, miRNA delivery seems a very promising resource for applications in bone formation strategies, at least for the possibility it may give for regulating osteogenesis and bone cell differentiation in vitro [157].

Therefore, in order to be suitable for bone tissue engineering, a scaffold should integrate, as much as possible, the properties of native bone tissue. The scaffold should then closely reproduce tissue architecture, and combine the nanoscale topography of ECM with its relative higher-scale micro- / meso/ and macro-structures [158-160], since surface topography influences the rate of bone differentiation, formation, repair, and angiogenesis, as well [161-164]. Surface topography can also control BM-derived MSCs proliferation and differentiation, and it has been shown to play a major role than surface chemistry in regulating cell commitment. These processes are, at least in part, 
regulated by cell shape, and could involve cytoskeleton organization, membrane tension, cell adhesion molecules and cell-cell interactions $[42,145,165]$.

Newborn-rat calvaria-derived osteogenic cells, as well as MG63 cells, were seeded on titanium or titanium alloy surfaces harboring different topographies $[166,167]$. Cell behavior [adhesion, differentiation, matrix mineralization and bioactive molecules synthesis (VEGF, TGF- $\beta 1$, FGF-2, and angiopoietin-1], were differently controlled by the characteristics of the surface, rough surface favoring always the expression of the differentiated phenotype. Osteoblasts are sensitive to surface roughness, and the discontinuous-type topographies, by altering cell adhesion, shape, migration and differentiation (and acting, in part, by signaling pathways involving $\alpha 2 \beta 1$ integrins, FAK and phosphorylative processes), could represent an efficient strategy for coating low osteoconductive biomaterials and for increasing osseointegration [168-171].

Both biochemical and biophysical aspects of ECM should be taken into account to reach a better cell homeostasis and to favour ulterior bone integration.

\subsubsection{Scaffold composition}

The main components of materials used as scaffolds and developed for bone engineering, are metals, polymeric materials (natural or synthetics), and ceramics.

\subsection{Metals}

Even if metals present the advantage to furnish an immediate mechanical support, their use is limited by their poor integration with the host tissue, by the release of ions, and by the possible bone collapse because of secondary fatigue loading [172]. Whereas stainless steel was highly used in the past, titanium and, mainly, titanium alloys are, at present, the most widely studied metal components for bone engineering techniques. Metal surfaces have been modified by changing their local topography and / or chemistry, in order to increase the possibility of cell interactions with the metallic supports, the rate of mesenchymal cell differentiation, and to facilitate implant integration in the site of injured tissues [86,173-176]. In vitro studies demonstrated that the osteoblastic cell line MG63 behaves differently, according to the roughness of titanium, and of titanium alloys [177-179]. Microroughness was shown to favor osteoblastic proliferation and differention, while cell number was decreased. Moreover, these processes are, at least in part, mediated by $\alpha 2 \beta 1$ integrins $[86,180,181]$. However, as noticeably reviewed by Anselme and coworkers [182], results are often contradictory, because of a scarce homogeneity in the scaffold preparation and roughness characterization.

\subsection{Polymers}


Natural polymers. Natural biopolymers can be made of various molecules (e.g. collagen, fibrinogen, chitosan, alginate, starch, hyaluronic acid, silk, fibrin and poly(hydroxybutyrate)) [172,183-185]. They present the great advantages to be osteoinductive materials and naturally biodegradable substances. They generally support well cell attachment, they can guide cell migration and differentiation, but are often too weak to face the biomechanical forces imposed by daily activities. To overcome such a limit, and in order to reinforce material stability, natural biomaterial can be cross-linked, or associated with synthetic polymers or ceramics/bioactive glasses, in order to create biocomposite materials [186,187]. Kane and co-workers [187] reinforced collagen scaffolds with HA, and obtained a highly porous and interconnected biomaterial, able to support angiogenic and osteogenic differentiation after implantation in ectopic site (in vivo), or to favor the differentiation of adipose-derived MSCs (in vitro). It is of importance to keep in mind that the structural state of the polymers can profoundly modify the characteristics of the resulting scaffold. For example, Tsai and co-workers [186] demonstrated that, whereas soluble and fibrillar forms of type I collagen were able to stimulate the growth of MG-63 cells, the denatured form was more adequate in guiding cell differentiation. Biopolymers can also be used to cover hard implant surface, in order to increase osteoconduction, osteoinduction, and osseointegration. The 3D macroporous arrangement of silk-based or biocomposite scaffolds made up of collagen and HA is very interesting, since it mimics some aspects of bone porosity, and favors bone repair $[189,190]$.

Synthetic polymers. Synthetic polymers represent the most widely used biomaterials in tissue engineering. Many techniques can be used as a means to prepare synthetic polymer-based scaffolds [191]. Synthetic biomaterials include poly( $\alpha$-hydroxy acids), PCL, poly(propylene-fumarates), polycarbonates, polyphosphazenes, and polyanhydrides [172]. The $\operatorname{poly}(\alpha-$ -hydroxy acids) group comprises PLA, PGA, and their co-polymer PLGA. These synthetic polymers usually present the characteristic to be hydrolyzed into non-toxic byproducts (minimal systemic toxicity), and a poor immunoreactivity. PGLA copolymer was already tested in human patients, and, even if more slowly than autologous bone graft, it supported bone healing [192]. In vitro, a composite biomaterial made of chitosan and PLGA was shown to harbor some mechanical properties of trabecular bone, in addition to be osteoconductive and to support bone cells phenotype expression (production of ALP, OSP, BSPs) [193]. The functionalization of the chitosan / PLGA scaffold with a high loading of heparin, further stimulates MC3T3-E1 cells proliferation and differentiation [194]. Smith and co-workers [195] also demonstrated that the etching of PLGA with $\mathrm{NaOH}$ modifies the nano-scale surface topography of the manufact, and differently regulate cell behavior, according the cell type. Results from other authors suggest that, in addition to allow the spatio-temporal release of bioactive molecules, it is possible to devise a celltype specific scaffold. Smith and co-workers [195] think that it could be 
feasible to create a biphasic scaffold made up, first, of fibroblasts, in order to generate fibrocartilage, and, on the other pole, the scaffold could be treated with $\mathrm{NaOH}$, in order to allow osteoblasts adhesion and bone formation.

However, PLGA polymers, for example, could release acidic byproducts, rendering the local microenvironment inadequate for bone integration. To overcome such a limit, polymer blends were developed; the mixture of PGLA and polyphosphazenes was shown to neutralize the environment of biomaterial degradation [196,197]. PLLA is widely used in bioengineering, since, in addition to the fact of having been approved by the Food and Drug Administration (FDA), it is biocompatible and biodegradable. However, its poor mechanical properties hinder its routine use in orthopedics [198]; this is the reason why this polymer was further reinforced with fibers or with inorganic components, such as HA or bioactive glass. PLGA combined with bioactive glasses was shown to possess higher compressive properties, and to support osteoblasts attachment and differentiation [199].

\subsection{Ceramics}

HA, calcium phosphate, calcium sulphate, aluminia, zirconia, and coralline are also widely used as scaffolds for bone engineering $[126,200]$. They can be elaborated from natural or synthetic [e.g. sintered HA (sHA) and beta-tricalcium phosphate $(\beta$-TCP)] materials. Ceramics can be subdivised in inert, bioactive (sHA), and resorbable ( $\beta$-TCP) products, depending on their main properties. As already illustrated, different types of substances are available, the most common being phosphate calcium ceramics, but they do not possess identical surface chemistry, surface charges, wet ability, and, consequently, the same capability to interact with cells [201]. Among all ceramics, sHA and $\beta$-TCP are the most studied formulae; they can be used alone, or mixed together, with a ratio variable between the 2 components [202]. When they are grafted, they give rise to a bone-like apatite layer that favors the ulterior osseointegration. sHA presents the advantage to allow the creation of a 3D stable and rigid scaffold, with a defined porosity. $\beta$-TCP is resorbed quicker than sHA, and it is less tough. sHA is widely used for bone regeneration, because of its good biocompatibility and high osteoconduction attributes, while is too fragile and hard, and not sufficiently elastic to be used to repair large defects in load-bearing bones [203,204]. Biphasic forms of calcium phosphate component were developed, in order to optimize the osteogenic and mechanic properties of the biomaterial, as well as its biodegradability. Arinzeh and co-workers [205] compared 6 different biomaterials made up of sHA, $\beta$-TCP, or of composites of these two substances (in different ratios). They showed that, after ectopic implantation (in severe combined immunodeficiency (SCID) mice), the composite with $20 \%$ sHA and $80 \% \beta$-TCP better supports BM-MSCs, a faster osteoinduction, and the correlated differentiation into osteoblasts. The incorporation of rat or human MSCs into a composite biomaterial harboring a ratio of $60 \%$ sHA / $40 \% \beta$-TCP 
was shown to support the bridging of critical-sized defects [206]. Even if the resorbability of these scaffolds can be controlled by setting differently the mass ratio of sHA / $\beta$-TCP, it is difficult to fully direct the degradation of these ceramics, since they show a too limited resistance for being used in human patients with critical-sized bone defects. However, they can be poorly osteoinductive, and need to be functionalized. To counteract the poor efficiency in driving bone neo-formation, Choy and co-workers [207], incorporate RANKL onto $\beta$-TCP ceramic scaffold. Murine osteoclasts precursors seeded onto this support were able to mature, and to give rise to active osteoclasts expressing cathepsin $\mathrm{K}$, calcitonin receptor, the sodium / hydrogen exchanger NHA2 and an active TRAP.

Concerning the problem of friability, sometimes met with porous bioceramics, the coating of ceramics with biological compounds (i.e. gelatin or alginate) can notably increase their mechanical properties (either compressive strength, or elastic modulus) $[186,208]$. Biocomposites made of sHA or of calcium cements and natural (e.g. gelatin, collagen, chitosan) or synthetic [e.g. PLA, PLLA, PLGA, PCL, poly(propylene carbonate)] elastic polymers were also developed, in order to better mimic the physiological biocomposite bone structure, to reduce ceramic weakness, and to facilitate the shaping of the scaffold by surgeons. This association was largely shown to increase the efficiency of osteogenesis and mineralization (MSCs-derived cells), as well as the differentiation of osteoclasts [209-217]. The coating of PLLA fibers with sHA allowed human cord blood-derived stem cells to form bone-like structures when scaffolds and cells were implanted subcutaneously, avoiding also the induction of excessive inflammatory reaction [214]. By substituting phosphate ions with silicate ions, different bioceramic materials have been developed. The investigation in vivo (sheep) showed that also this peculiar ceramics are able to increase bone formation and development [218]. Another strategy was to develop bioactives glasses, or glass-ceramics materials, by incorporating, for example, silicon into calcium phosphate materials $[219,220]$. These silica-based bioglasses are able to quickly bond to bone through a carbonated apatite layer that forms on the surface of the biomaterial after its interaction with the body fluids. These bioglasses are degraded faster than mixture of glass and ceramic, and than, of course, sHA. According to Oonischi and co-workers [221], the rate of silica dissolution is correlated with the rate of bone differentiation and growth, rendering this kind of biomaterials interesting to be used for bone tissue engineering. The results obtained suggested, moreover, that the higher rate of bone formation could be due to the silica incorporated into the biomaterials. The bioactive glasses can also be prepared with a macroporous configuration that was usually shown to increase the formation of bone. In addition, bioactive glasses can be added to PLGA films, further increasing their mechanical properties and osteoconductivity, and the proliferation / differentiation rate of associated human osteoblasts [139]. One 
limit of these bioactive-glasses is their brittleness, and the difficulty to be properly shaped by the surgeon [222].

\subsection{Biomimetics}

De-cellularized / de-mineralized trabecular or cortical bones can be used as biomaterials, as well. They present the advantage to recapitulate the natural ECM features, and allow, therefore, attachment, proliferation and further differentiation of adipose-derived stem cells [129]. Usually, acellular ECM can be obtained after physical, chemical or enzymatic treatments [223,224]. According to the processing of demineralized bone, osteoconductive and osteoinductive properties can vary [84,225]. Moreover, following the treatments for preparing demineralized bone, a decrease of bone interconnectivity due to pore obstruction may occur. Bone-based scaffold can be also demineralized and functionalized with bioactive molecules [226]. Kim and co-workers [227] used another source of acellular ECM. The human lung fibroblast ECM can be used as natural scaffold, coupled with synthetic polymers (PLA, PLGA), and functionalized with the BMP-2 bioactive molecule. This composite material was shown to favor osteogenic differentiation, either in vitro or in vivo. In effect, the ectopic implantation of such a scaffold in the SCID mice, resulted in an increase in bone formation, while its graft in a rat calvarial bone defect promoted bone healing. However, whereas demineralized bone matrix is able to provide biochemical cues, it is not able to serve as a tough structural support.

\subsubsection{Nanoscale}

Nanoparticles or nanocapsules can be proposed as molecule delivery systems, able to allow the biochemical control of spatial and temporal release of signaling molecules, such as members of the TGF- $\beta$, BMP-2, and BMP-7 family, or of other bioactive molecules, such as proinflammatory cytokines and growth factors [e.g. TNF- $\alpha$, interleukins, interferon gamma (IFN $\gamma$ ), prostaglandins]. These "nanosystems" have been shown to regulate recruitment, migration and differentiation of bone cells, and, as in the in vivo conditions, to favor cell survival and to guide bone healing [228-231]. At the nanometer scale, it becomes possible to regulate cell interactions by means of specific proteins, so mimicking the nanocomposite structure of bone tissue. Nanostructured groove patterned biomaterial was shown to be able to induce osteoblasts to mimic, at least in part, their physiological behavior in response to a mechanical stimulus (longitudinal stretching), whereas microstructured biomaterials did not induce such a response [232], then suggesting that, for a proper bone cells activity, the nanotopography of scaffolds needs to be taken into consideration. Nanobiomaterials can be produced in different structures / shapes, such as nanofibers, nanotubes, nanowires, nanoparticles, nanocrystals or nanocomposites. Because of their nanometer scale, scaffold properties can be optimized by engineering their surface topography and chemistry, taken into 
account that wetness and surface energy become, at the nanometer length scale, important parameters involved in the control of cell behavior. Nanostructured scaffolds were developed to optimize cell-scaffold interactions, and to physically guide the differentiation of mesenchymal stem cells and bone progenitors. The nanometer level $(<100 \mathrm{~nm}$ for the minor dimension) is of importance, since it is the level at which cells-biomaterials can interact, due to the possibility to adsorb proteins on the surface and, then, to sustain a further development of the engineered tissue-biocomposite assembly $[233,234]$. Nanotopography and nanostructure of scaffold surface were shown to direct cell behavior (thus determining / conditioning the features), even in the absence of growth factors or of other chemiotactic agents [163,235], underlining the importance of such parameters in developing new scaffolds.

The progress of technologies allows now to create new and efficient nanomaterials able to mimic, as much as possible, the native bone hierarchy.

\subsection{Nanofibers and nanotubes}

This group of nanomaterials was developed because these nano-scaled biomaterials present a structure very similar to some ECM components, such as collagen fibrils. They also present a high surface area to volume ratio, that, after the functionalization of the biomaterial surface, it is important in order to increase osteoconduction and/or osteoinduction. Kumar and co-workers [145] tested a broad range of biomaterials for their capacity to interact with BM-derived MSCs. They showed that the only scaffolds able to guide MSCs through the osteoblastic lineage were the nanofibrous arranged biomaterials. The main polymers used to electrospun nanofibers are PLA, PGA, PLGA and PCL, but some of them still present limitations relating to cell adhesion (caused by their hydrophobic characteristics), and restrictions due to the harmless of their degradations byproducts. On the contrary, PCL nanofibers allow rat BM-derived MSCs to adhere, to proliferate up to form cell multilayer coating of the scaffold, and, after 4 weeks of culture, to express markers of differentiated osteoblasts (i.e. mineralization and synthesis of type I collagen) [236]. Carbon nanotubes present optimal electrical and mechanical properties that can be exploited for bone engineering, even if they need to be functionalized, in order to be able to better favor calcium mineralization, and to reduce any possible cytotoxic outcome [237]. The conjugation of carbone nanotubes with different molecular groups (e.g. $\mathrm{COOH}$ or $\mathrm{NH}_{2}$ ) is possible, and favors $\mathrm{HA}$ mineralization process. The functionalization, in addition to increasing the biocompatibility of the biomaterial, can also regulate the strength of the fibers. Another important attribute of functionalization is that it can modify the surface free energies, shown to play an important role in cell adhesion and functions [238-241]. Another advantage of the electrospun nanofibers is that, in the presence of osteogenic culture medium, they regulate cell morphology, proliferation and sustain stem cells differentiation, in a manner dependent on fibers' alignment and diameter $[242,243]$. This fact may allow for guiding progenitor / stem cell 
differentiation by modulating the manufacture of the nanofibers. However, this kind of nanofibrous scaffold presents a poor resistance to mechanical stress. On the contrary, nano-composites scaffolds made of $\beta$-TCP and sHA nanofibers, were shown to be tougher than non-composite biomaterials $(\beta$-TCP ceramics alone), and to reach compressive properties close to the ones of the trabecular bone in vivo [244]. Venugopal and Vadgama [245] maintained in culture human fetal osteoblasts on collagen / PLC / sHA composite nanofibers and showed that such organic-inorganic meld favors cell adhesion, migration, proliferation and mineralization. A biocomposite made of electrospun PCL nanofibers and nanoparticles of allogenic bone ECM has been demonstrated to highly favor the in vivo osteogenic differentiation of adipose-derived stem cells, when compared to the influence of PCL fibers without ECM nanoparticles on the same cell type [246]. The versatility of electrospun scaffolds is also based on their capacity to be processed with bioactive molecules and / or HA. As an example, a silk poly(ethylene oxide) (PEO) scaffold, harboring both BMP-2 and HA nanoparticles, was proved to induce human BM-derived MSCs to differentiate into osteoblastic cells, which, with respect to controls, were characterized by the expression of BSP, type I collagen, and by a significant increase of BMP-2 expression and matrix mineralization [247].

\subsection{Nanoparticles}

sHA was developed as nanocrystalline sHA to better mimic the in vivo situation, and was used to improve materials' biocompatibility and conduction. When MG-63 cells were seeded onto films made of various-sized sHA, the results indicated that the nanoparticles of sHA support cell proliferation and inhibit apoptosis better than the microparticles [248]. Nanoparticles of sHA has been shown to be osteoconductive as amorphous calcium phosphate, functionalized with the RGD sequences [249]. The nanoparticles of sHA are particularly appreciated for the great surface area they expose, for the roughness of their surface, and, also, for their surface energy and the arranged distribution of their electrons [250]. Moreover, in addition to coat biomaterials, sHA nanoparticles can also be used as fillers. Many techniques can be used to prepare sHA nanoparticles, and each of them gives its own sHA conformation, size and the possibility to create biocomposites [251].

\subsection{Nanostructured biomaterials}

ECM Hydrogels could better recapitulate some bone matrix properties, such as structure and high porosity, and provide a large surface area that sustains the adsorption of adhesive proteins. Hydrogels usually consent an easy exchange of nutrients and gas up the central part of the scaffolds. They are, furthermore, easy to manipulate: for example, the linking of protein receptors to the scaffold can control cell behavior (shape, growth, differentiation, functions) [252]. Co-polymerization of degradable and non-degradable macromers permits to monitor hydrogel degradation and concomitant expression of osteoblastic 
phenotype and mineral deposit [253]. Concerning fabrication, among the various materials that can be used to create nanostructured hydrogels, some are synthetic polymers [such as poly(vinyl alcohol) (PVA) or PEO], while others are of natural origin (collagen, alginate, chitosan, fibrin, silk, fibrinogen, gellan gum, etc.). However, hydrogels present often too poor mechanical properties to be used in orthopedic field. This is the reason why they are often combined with other biomaterials (e.g. inorganic substances such as sHA, $\beta$-TCP or bioactive glasses) in order to improve their strength [254]. As an example, gellan-gum hydrogels reinforced by the addition of bioactive glass nanoparticles, became able to sustain cell adhesion and viability [254].

Another application of nanostructured surfaces in bone repair was developed by Rani and co-workers [255], who showed that the fabrication of non-periodic nanostructures renders biocompatibles the scaffold that they cover. Moreover, according to the arrangement of the nanostructures (nanoscaffolds, nanoleaves, or nanoneedles), the expression of some osteoblastic markers is distinctly regulated, as their osteointegration differs in efficiency.

Nanocomposite materials. First of all, being nanocomposites formed by, at least, two materials, the resultant of the sum of the properties of the biomaterials they are composed of, should surpass (in number or quality) the complex of properties of each individual element. For example, sintering HA bioceramics, thanks to the high surface energy encountered in nanomaterials, can increase the mechanical properties of the biomaterial. Combining sHA particles and chitosan, has permitted to prepare nanocomposites rods with stronger mechanical properties [256]. Biocomposites scaffolds made of nanostructured phosphates and natural biopolymers (nanoHA-Si-Mg-Zn / type I collagen / chitosan) and organized according the layer-by-layer method, were able to allow BM-derived MSCs adhesion, remodeling of the scaffold surface by cells into a more bone-like structure [257]. Bhattacharya and Chaudhry [258] successed in preparing nanocomposites made of silica nanoparticles and PVA and presenting bone similar properties. The osteoinductivity of microscale-bioactive glasses can be optimized, by switching from the micro- to the nano-scale level [259]. Bearing in mind that bone is a composite material made of inorganic and organic phases, it is straightforward to consider that sHA or bioactive glasses could be combined with nanofibers of polymers to form nanocomposites. In addition to sHA, polymers that can be used are, for example, synthetic polymers (PLGA, PLLA, PCL, PVA) and natural-based polymers (starch, chitosan, silk, collagen). Nanoceramic composites of PLGA and nano-HA were used to increase biocompatibility of the PLGA component. The 3D culture of mesenchymal stem cells with these biocomposite scaffolds in the fluid-dynamic RCCS ${ }^{\mathrm{TM}}$ bioreactor, sustains good osteoconduction and osteoinduction, and an efficient osteogenesis [260]. Recently, scaffolds made of poly(D,L-lactide) (PDLLA), carbon nanotubes and nano-HA have been developed, and shown to be able to promote cell viability, 
differentiation, and matrix mineralization. In vivo, such scaffolds allowed the formation of an immature bone, indicating that the combination of several components can improve tissue engineering efficiency [261].

\subsection{CONCLUSIONS}

Regulation of bone homeostasis and healing is complex, and encompasses a multiplicity of actors that intimely interact and cooperate to reach the best bone quality in health and illness. When nature is no more able to counteract bone injury, tissue engineering must take the measures, bearing in mind the multi-signaling networks involved in bone formation, maturation and functions, which include biochemical, physical, mechanical, topographical, and electrical inputs. As described previously, bone is a hierarchically organized, composite biomaterial, which includes tissue-specific ECM and multiple cell types: osteoblasts, osteocytes, osteoclasts, lining cells, and precursors. The 3D tissue organization, the defined cell polarization, the spatial and temporal localization of biochemical and mechanical signals, the specific cell-cell and cell-ECM molecular interactions, are fundamental characteristics (and requirements) for optimal tissue features and responses to various stimuli. Bone cells interact with a number of other cell types (e.g. endothelial cells, bone marrow cells, etc.), and bioactive molecules (e.g. cytokines, growth factors, hormones), synthesized by bone tissue-specific cells, as well as by neighboring or distant cells. Many engineering strategies have been developed during the last decades, in order to facilitate / permit the repair of injured bone unable to self-repair, either since affected by severe pathologies (e.g. osteoporosis, ischemic necrosis, neoplasia), or due to large loss of substance (large-sized defect).

Even if great efforts have been addressed in order to optimize bone cell culturing / transplantation strategies and the design / fabrication techniques for the manufacture of suitable scaffolds / bioreactors, translational medicine (and bone tissue engineering) still needs new approaches, in order to allow a more efficient treatment of orthopaedic patients.

A significant number of nanomaterials has been already conceived and developed in recent years, aimed at optimizing bone tissue engineering strategies; nevertheless, none of these products has, at present, been successfully used in humans for bone repairing procedures. Table 1 shows some examples of already developed nanomaterials, with their relative "field(s) of application" (basic research, in vitro/in vivo pre-clinical study, and translational use at clinical level). Among all the various nanomaterials, nanoparticles are, at present, the only ones employed in the medical context, as drug or growth factor vehicles; bone cements and injectable materials (not necessarily nanoscaled), able to polymerize and harden in situ, are becoming very interesting, even if not yet ready to be used in orthopaedic contexts. 
Table 1. Examples of nanomaterials use in bone research, from bench to clinic

\begin{tabular}{|c|c|c|c|c|}
\hline & 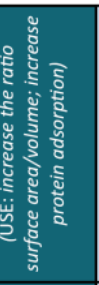 & 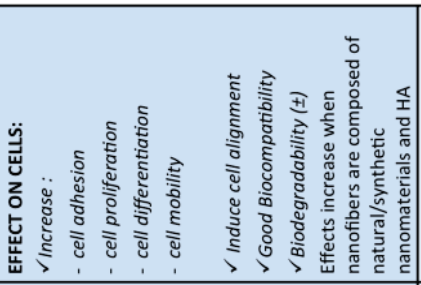 & 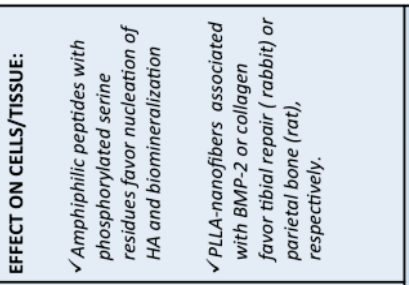 & 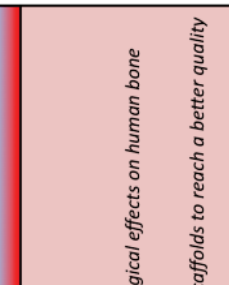 \\
\hline & 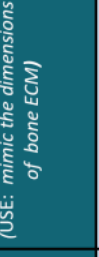 & 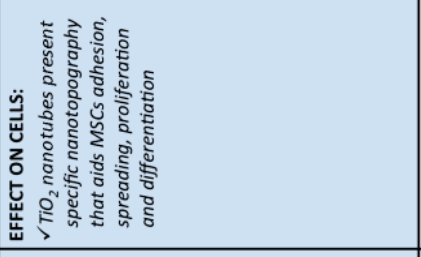 & 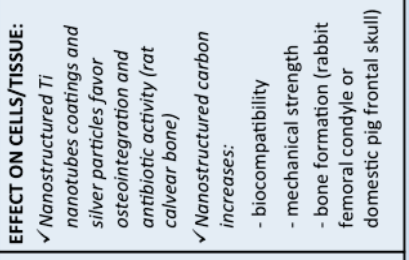 & 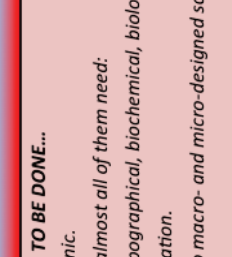 \\
\hline & 然 & 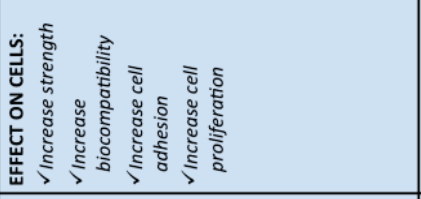 & 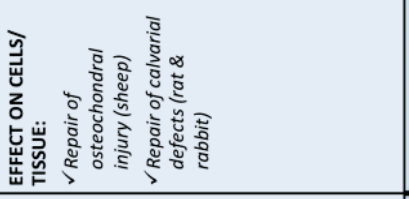 & 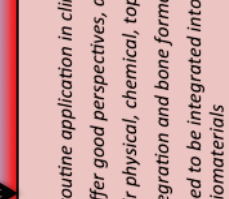 \\
\hline & 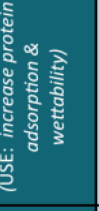 & 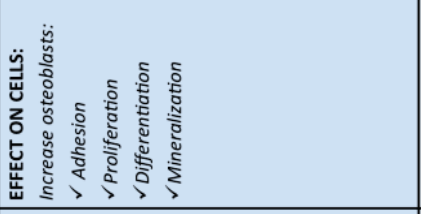 & 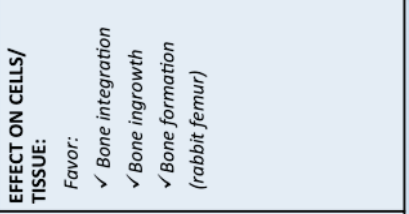 & 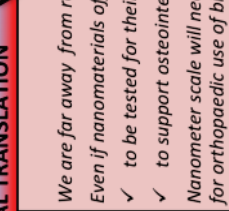 \\
\hline & 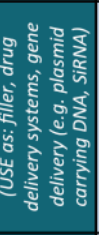 & 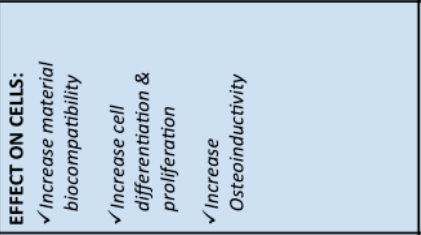 & 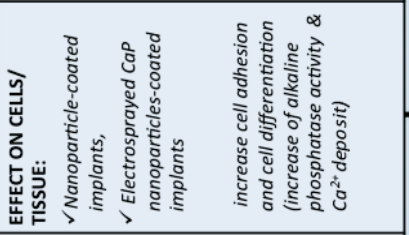 & 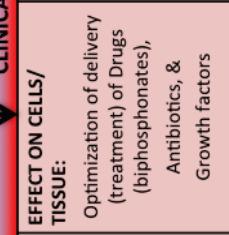 \\
\hline & 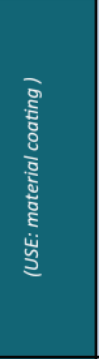 & 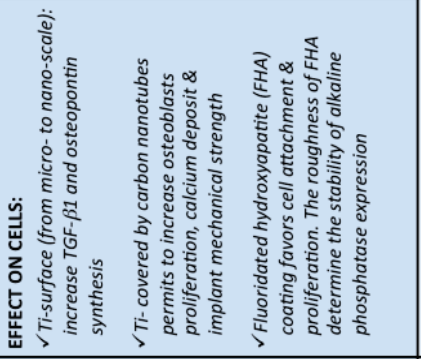 & 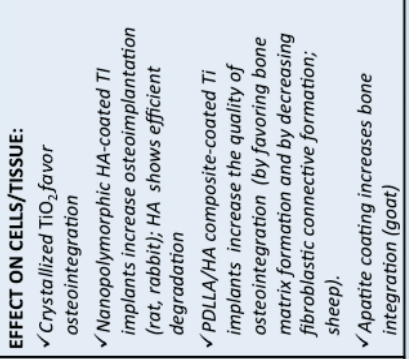 & 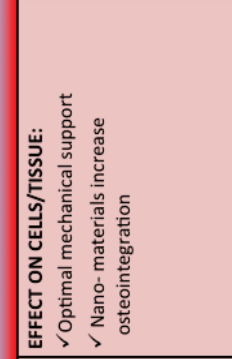 \\
\hline & & 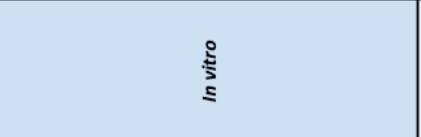 & 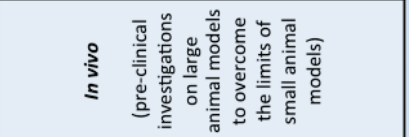 & 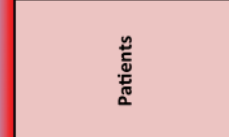 \\
\hline & & \multicolumn{2}{|c|}{ 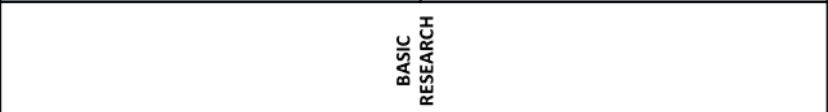 } & 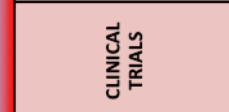 \\
\hline
\end{tabular}


Contrary to nanomaterials, nano-coating technologies applied to metal or alloy implants are easier applicable in clinic, where the nanoscaled size of the coating has been already demonstrated to favor implant integration in the site of bone injury, thus suggesting that this strategy is consistently promising.

In conclusion, as bone properties result from the interactions of its cellular and organic / inorganic components at the macro-, meso-, micro- and nano-scale level, it is intuitive to expect that the perfect bone bio-substitute (graft extender, void filler, etc.) should imply that the bioengineering approach aimed at designing this complex tissue requires multiple assembly/fabrication controls, up to the nanoscale level. The extraordinary technological progress attained in the last 10 years, together with the advance in our knowledge of bone physiopathology (coupled with the new holistic visions from the fields of systems and emergence biology), will open wide perspectives to innovative applications of nanoscale structures to bone tissue engineering, thus providing new powerful tools for improving its strategies for medical applications.

\section{AKNOWLEDGEMENTS}

The authors are thankful to Mrs. Jennifer Boniotti, for her precious help in the preparation of the manuscript.

This work has been partially supported by EC funds (grant number: LIFE12 ENV/IT/000614), and was conducted within the scientific activities of the inter-departmental Research Center "Adattamento e Rigenerazione Tessutale $e$ d'Organo" (ARTO), of the University of Brescia, Italy. 


\section{REFERENCES}

1. K.J. Oldknow, V.E. MacRae, C. Farquharson. J. Endocrinol. 225 (2015) R1-R19.

2. Y. Bala, E. Seeman. Calcif. Tissue Int. (2015) [Epub ahead of print].

3. P. Ducy, M. Amling, S. Takeda, M. Priemel, A.F. Schilling, F.T. Beil, J. Shen, C. Vinson, J.M. Rueger, G. Karsenty. Cell 100 (2000) 197-207.

4. H.K. Väänänen, H. Zhao, M. Mulari, J.M. Halleen. J Cell Sci. 113 (2000) 377-381.

5. H.K. Väänänen, T. Laitala-Leinonen. Arch. Biochem. Biophys. 473 (2008) 132-138.

6. Y. Hashida, K. Nakahama, K. Shimizu, M. Akiyama, K. Harada, I. Morita. Bone 61 (2014) 19-26.

7. V.J. Vigorita, in Orthopaedic Pathology, $2^{\text {nd }}$ Ed., W. Kluwer (Ed.), Lippincott Williams \& Wilkins, 2008, New York, USA, pp. 1-49.

8. A. Tampieri, S. Sprio, M. Sandri, F. Valentini. Trends Biotechnol. 29 (2011) 526-535.

9. D.A. Wang, M. Miura, H. Demura, K. Sato. Endocrinology 138 (1997) 2953-2962.

10. T.J. Martin, N. Udagawa. TEM 9(1998) 6-12.

11. H.M. Kronenberg. Nature 423(2003) 332-336.

12. M. Sinnesael, S. Boonen, F. Claessens, E. Gielen, D. Vanderschueren. J. Osteoporosis (2011) ID240328.

13. V. Toppets, V. Pastoret, V. De Behr, N. Antoine, C. Dessy, A. Gabriel. Ann. Méd. Vét. 148 (2004) 1-13.

14. R.S. Tuan. J. Bone Joint Surg. Am. 85-A (2003) 137-141.

15. B. Guillotin, R. Bareille, C. Bourget, L. Bordenave, J. Amédée. Bone 42 (2008) 1080-1091.

16. M.M. Thi, M. Urban-Maldonado, D.C. Spay, S.O. Suadicani. Am. J. Physiol. Cell Physiol. 299 (2010) C994-C1006.

17. E. Haÿ, F.X. Dieudonné, Z. Saidak, C. Marty, J. Brun, S. Da Nascimento, P. Sonnet, P.J. Marie. J. Cell Physiol. 229 (2014):1765-1775.

18. F. Lecanda, P.M. Warlow, S. Sheikh, F. Furlan, T.H. Steinberg, R. Civitelli. J. Cell Biol. 151 (2000) 931-943.

19. A.R. Guntur, C.J. Rosen, M.C. Naski. Bone 50 (2012) 54-62.

20. T.L. Andersen, T.E. Sondergaard, K.E. Skorzynska, F. Dagnaes-Hansen, T.L. Plesner, E.M. Hauge, T. Plesner, J.M. Delaisse. Am. J. Pathol. 174(2009) 239-247.

21. J.S. Nyman, M. Reyes, X. Wang. Micron 36 (2005) 566-582.

22. Y. Han, S.C. Cowin, M.B. Schaffler, S. Weinbaum. Proc. Natl. Acad. Sci. USA 101 (2004) 16689-16694.

23. A. Vatsa, R.G. Breuls, C.M. Semeins, P.L. Salmon, T.H. Smit, J. Klein-Nulend. Bone 43 (2008) 452-458.

24. A. Vatsa, C.M. Semeins, T.H. Smit, J. Klein-Nulend. Biochem. Biophys. Res. Commun. 377 (2008) 1019-1024.

25. J. Behari, Biophysical Bone behavior: principles and applications. John Wiley \& Sons Pte Ltd, Chichester, UK, 2009, pp. 129-172.

26. R.K. Globus, A. Moursi, D. Zimmerman, J. Lull, C. Damsky. ASGSB Bulletin 8 (1995) 19-28.

27. N. Reznikov, R. Shahar, S. Weiner. Acta. Biomaterialia 10 (2014) 3815-3826. 
28. L. Gibson, M. Ashby, In Cellular Solids, Structure and Properties (2 ${ }^{\text {nd }}$ Ed.), Cambridge University Press, Cambridge, UK, 1999.

29. D.R. Carter, D.M. Spengler. Clin. Orthop. Relat. Res. 135 (1978) 192-217.

30. M.W. Hamrick, J.G. Skedros, C. Pennington, P.L. McNeil. J. Musculoskelet. Neuronal Interact. 6(2006) 258-263.

31. S. Takeda, F. Elefteriou, R. Levasseur, X. Liu, L. Zhao, K.L. Parker, D. Armstrong, P. Ducy, G. Karsenty. Cell 111(2002) 305-317.

32. V.K. Yadav, F. Oury, N. Suda, Z.W. Liu, X.B. Gao, C. Confavreux, K.C. Klemenhagen, K.F. Tanaka, J.A. Gingrich, X.E. Guo, L.H. Tecott, J.J. Mann, R. Hen, T.L. Horvath, G. Karsenty. Cell 138 (2009) 976-989.

33. N. Fukushima, R. Hanada, H. Teranishi, Y. Fukue, T. Tachibana, H. Ishikawa, S. Takeda, Y. Takeuchi, S. Fukumoto, K. Kangawa, K. Nagata, M. Kojima. J. Bone Miner. Res. 20 (2005) 790-798.

34. C. Ma, T. Fukuda, H. Ochi, S. Sunamura, C. Xu, R. Xu, A. Okawa, S. Takeda. Mol. Metab. 4 (2015) 175-185.

35. S.R.L. Young, R. Gerard-O'Riley, J.B. Kim, F.M. Pavalko. J. Bone Miner. Res. 24 (2009) 411-424.

36. A.B. Castillo, J.T. Blundo, J.C. Chen, K.L. Lee, N.R. Yereddi, E. Jang, S. Kumar, W.J. Tang, S. Zarrin, J.B. Kim, C.R. Jacobs. PLoS One 7 (2012) e43291.

37. H.J. Donahue. Bone 26 (2000) 417-422.

38. A. Liedert, D. Kaspar, R. Blakytny, L. Claes, A. Ignatius. Biochem. Biophys. Res. Commun. 349 (2006) 1-5.

39. Y. Mikuni-Takagaki. J. Bone Miner. Metab. 17 (1999) 57-60.

40. L. Tang, Z. Lin, Y.M. Li. Biochem. Biophys. Res. Commun. 344 (2006) 122-128.

41. M. Jagodzinski, M. Drescher, J. Zeichen, S. Hankemeier, C. Krettek, U. Bosch, M. van Griensven. Eur. Cell Mater. 7 (2004) 35-41.

42. R. McBeath, D.M. Pirone, C.M. Nelson, K. Bhadriraju, C.S. Chen. Dev. Cell 6 (2004) 483-495.

43. I. Titushkin, M. Cho. Biophys. J. 93 (2007) 3693-3702.

44. J.A. Robinson, M. Chatterjee-Kishore, P.J. Yaworsky, D.M. Cullen, W. Zhao, C. Li, Y. Kharode, L. Sauter, P. Babij, E.L. Brown, A.A. Hill, M.P. Akhter, M.L. Johnson, R.R. Recker, B.S. Komm, F.J. Bex. J. Biol. Chem. 281(2006) 31720-31728.

45. E.J. Arnsdorf, P. Tummala, A.B. Castillo, F. Zhang, C.R. Jacobs. J. Biomech. 43 (2010) 2881-2886.

46. S. Viguet-Carrin, P. Garnero, P.D. Delmas. Osteoporos. Int. 17 (2006) 319-336.

47. M. Zaidi. Nature Med. 13(2007) 791-801.

48. S. Isenmann, A. Arthur, A.C. Zannettino, J.L. Turner, S. Shi, C.A. Glackin, S. Gronthos. Stem Cells 27(2009) 2457-2468.

49. S. Kido, R. Kuriwaka-Kido, T. Imamura, Y. Ito, D. Inoue, T. Matsumoto. Bone $\mathbf{4 5}$ (2009) 1125-1132.

50. M. Gyda, S. Corisdeo, M. Zaidi, B.R. Troen. Biochem. Biophys. Res. Commun. 285 (2001) 328-334.

51. K. Nakashima, X. Zhou, G. Kunkel, Z. Zhang, J.M. Deng, R.R. Behringer, B. de Crombrugghe. Cell 108 (2002) 17-29.

52. T.J. Martin, N.A. Sims. Rev. Endocr. Metab. Disord. 2015 Jan 4 [Epub ahead of print].

53. C.B. Khatiwala, S.R. Peyton, A.J. Putnam. Am. J. Physiol. Cell Physiol. 290 (2006) C1640-C1650. 
54. C.A. Mullen, M.G. Haugh, M.B. Schaffler, R.J. Majeska, L.M. McNamara. J. Mech. Behav. Biomed. Mater. 28 (2013) 183-194.

55. R. Civitelli. Arch. Biochem. Biophys. 473 (2008) 188-192.

56. T.J. Heino, T.A. Hentunen, H.K. Väänänen. Exp. Cell Res. 294 (2004) 458-468.

57. E. Birmingham, G.L. Niebur, P.E. McHugh, G. Shaw, F.P. Barry, L.M. McNamara. Eur. Cell Mater. 23 (2012) 13-27.

58. L.M. McNamara, R.J. Majeska, S. Weinbaum, V. Friedrich, M.B. Schaffler. Anat. Rec. (Hoboken) 292 (2009) 355-363.

59. L.E. Lanyon. Calcif. Tissue Int. 53 (1993) S102-S107.

60. R.G. Bacabac, D. Mizuno, C.F. Schmidt, F.C. MacKintosh, J.J. Van Loon, J. Klein-Nulend, T.H. Smit. J. Biomech. 41 (2008) 1590-1598.

61. R.F.M. Van Oers, H. Wang, R.G. Bacabac. Curr. Osteoporos. Rep. 13 (2015) 61-66.

62. W.J. Boyle, W.S. Simonet, D.L. Lacey. Nature 423 (2003) 337-342.

63. H. Yasuda, N. Shima, N. Nakagawa, K. Yamaguchi, M. Kinosaki, S. Mochizuki, A. Tomoyasu, K. Yano, M. Goto, A. Murakami, E. Tsuda, T. Morinaga, K. Higashio, N. Udagawa, N. Takahashi, T. Suda. Proc. Natl. Acad. Sci. USA 95 (1998) 3597-3602.

64. N. Udagawa, N. Takahashi, E. Jimi, K. Matsuzaki, T. Tsurukai, K. Itoh, N. Nakagawa, H. Yasuda, M. Goto, E. Tsuda, K. Higashio, M.T. Gillespie, T.J. Martin, T. Suda. Bone 25(1999) 517-523.

65. S.C. Manolagas. Bone 17 (1995) 63S-67S.

66. P. Ducy. Med. Sci. 12 (2001) 1242-1251.

67. J.T. Warren, W. Zou, C.E. Decker, N. Rohatgi, C.A. Nelson, D.H. Fremont, S.L. Teitelbaum. J. Cell Biochem. (2015) [Epub ahead of print].

68. N.S. Soysa, N. Alles, D. Weih, A. Lovas, A.H. Mian, H. Shimokawa, H. Yasuda, F. Weih, E. Jimi, K. Ohya, K. Aoki. J. Bone Miner. Res. 25 (2010) 809-818.

69. G.D. Roodman. Endocr. Rev. 17 (1996) 308-332.

70. A. Cappariello, A. Maurizi, V. Veeriah, A. Teti. Arch. Biochem. Biophys. 561 (2014) 13-21.

71. J.Y. Rho, L. Kuhn-Spearing, P. Zioupos. Med. Eng. Phys. 20 (1998) 92-102.

72. S. Weiner, W. Traub. FASEB J. 6 (1992) 879-885.

73. S. Weiner, H.D. Wagner. Ann. Rev. Mat. Sci. 28 (1998) 271-298.

74. $\quad$ S.V. Dorozhkin. Materials 2 (2009) 399-498.

75. E. Seeman. J. Gerontol. A Biol. Sci. Med. Sci. 68(2013) 1218-1225.

76. P. Fratzl, H.S. Gupta, E.P. Paschalis, P. Roschger. J. Mater. Chem. 14 (2004) 2115-2123.

77. D.R. Katti, S.M. Pradhan, K.S. Katti. J. Biomech. 43 (2010) 1723-1730.

78. Z. Qin, A. Gautieri, A.K. Nair, H. Inbar, M.J. Buehler. Langmuir 28 (2012) 1982-1992.

79. G.L. Barnes, P.J. Kostenuik, L.C. Gerstenfeld, T. A. Einhorn. J. Bone Miner. Res. 14 (1999) 1805-1815.

80. P. Guihard, M.A. Boutet, B. Brounais-Le Royer, A.L. Gamblin, J. Amiaud, A. Renaud, M. Berreur, F. Rédini, D. Heymann, P. Layrolle, F. Blanchard. Am. J. Pathol. 185 (2015) 765-775.

81. H.P. Gerber, T.H. Vu, A.M. Ryan, J. Kowalski, Z. Werb, N. Ferrara. Nat. Med. 5 (1999) 623-628.

82. E. Zelzer, W. McLean, Y.S. Ng, N. Fukai, A.M. Reginato, S. Lovejoy, P.A. D'Amore, B.R. Olsen. Development 129(2002) 1893-1904. 
83. X. Li, Z. Wang, L. Yang, Z. Li, Y. Ogata. J. Oral Sci. 52 (2010) 221-229.

84. J.L. Russell, J.E. Block. Orthopedics 22 (1999) 524-531.

85. R. Langer, J.P. Vacanti. Science 260 (1993) 920-926.

86. P. Carmeliet, R.K. Jain. Nature 407 (2000) 249-257.

87. J. Street, M. Bao, L. deGuzman, S. Bunting, F.V. Jr Peale, N. Ferrara, H. Steinmetz, J. Hoeffel, J.L. Cleland, A. Daugherty, N. van Bruggen, H.P. Redmond, R.A. Carano, E.H. Filvaroff. Proc. Natl. Acad. Sci. USA 99 (2002) 9656-9661.

88. A.L. Raines, R. Olivares-Navarrete, M. Wieland, D.L. Cochran, Z. Schwartz, B.D. Boyan. Biomaterials 31(2010) 4909-4917.

89. D.A. Puleo, R. Bizios. J. Biomed. Mater. Res. 26 (1992) 291-301.

90. K. Anselme. Biomaterials 21 (2000) 667-681.

91. T. Albrektsson, C. Johansson. Eur. Spin. J. 10 (2001) S96-101.

92. Y. Zhang, A. Schedle, M. Matejka, X. Rausch-Fan, O. Andrukhov. Cell. Mol. Biol. Lett. 15 (2010) 517-529.

93. A. Hofmann, U. Ritz, S. Verrier, D. Eglin, M. Alini, S. Fuchs, C.J. Kirkpatrick, P.M. Rommens. Biomaterials 29 (2008) 4217-4226.

94. J.Y. Kim, G.Z. Jin, I.S. Park, J.N. Kim, S.Y. Chun, E.K. Park, S.Y. Kim, J. Yoo, S.H. Kim, J.W. Rhie, D.W. Cho. Tissue Eng. 16 (2010) 2229-2236.

95. M. Magatti, S. De Munari , E. Vertua , C. Nassuato , A. Albertini , G.S. Wengler, O. Parolini. Cell Transplant 18 (2009) 899-914.

96. R.A. Banas, C. Trumpower, C. Bentlejewski, V. Marshall, G. Sing, A. Zeevi. Hum. Immunol. 69 (2008) 321-328.

97. B.J. Jones, S.J. McTaggart. Exp. Hematol. 36 (2008) 733-741.

98. Y. Diao, Q. Ma, F. Cui, Y. Zhong. J. Biomed. Mater. Res. A 91 (2009) 123-131.

99. G.I. Im, Y.M. Shin, K.B. Lee. Osteoarthritis Cartilage 13 (2005) 845-853.

100. C. Seebach, D. Henrich, C. Kähling, K. Wilhelm, A.E. Tami, M. Alini, I. Marzi. Tissue Eng. Part A 16 (2010) 1961-1970.

101. T. Matsumoto, A. Kawamoto, R. Kuroda, M. Ishikawa, Y. Mifune, M. Iwasaki, M. Miwa, M. Horii, S. Hayashi, A. Oyamada, H. Nishimura, S. Murasawa, M. Doita, M. Kurosaka, T. Asahara. Am. J. Pathol. 169 (2006) 1440-1457.

102. A. Bernhardt, S. Thieme, H. Domaschke, H. Springer, A. Rosen-Wolff, M. Gelinsky. J. Biomed. Mater. Res. Part A 95A (2010) 848-856.

103. G.M. de Peppo, I. Marcos-Campos, D.J. Kahler, D. Alsalman, L. Shang, G. Vunjak-Novakovic, D. Marolt. Proc. Natl. Acad. Sci. USA 110 (2013) 8680-8685.

104. B.D. Riehl, J.Y. Lim. Cells 1 (2012) 1225-1245.

105. P.S. Ayyaswamy, K. Mukundakrishnan. Acta Astronaut 60 (2007) 397-405.

106. F. Cosmi, N. Steimberg, D. Dreossi, G. Mazzoleni. J. Mech. Behav. Biomed. Mater. 2 (2009) 164-172.

107. F. Cosmi, N. Steimberg, G. Mazzoleni. J. Mech. Behav. Biomed. Mater. 44C (2015) 61-70.

108. T.G. Hammond, J.M. Hammond. Am. J. Physiol. Renal. Physiol. 281 (2001) F12-F25.

109. X. Yu, E.A. Botchwey, E.M. Levine, S.R. Pollack, C.T. Laurencin. Proc. Natl. Acad. Sci. USA 101 (2004) 11203-11208.

110. C. Morabito, N. Steimberg, G. Mazzoleni, S. Guarnieri, G. Fanò-Illic, M.A. Mariggiò. Biomed. Res. Int. 2015 (2015) 754283. 
111. C. Montani, N. Steimberg, J. Boniotti, G. Biasiotto, I. Zanella, G. Diafera, I. Biunno, L. Caimi, G. Mazzoleni, D. Di Lorenzo. Toxicol. Appl. Pharmacol. 280 (2014) 421-433.

112. M. Ferrarini, N. Steimberg, M. Ponzoni, D. Belloni, A. Berenzi, S. Girlanda, F. Caligaris-Cappio, G. Mazzoleni, E. Ferrero. PLoS One 8 (2013) e71613.

113. S.R. Facer, R.S. Zaharias, M.E. Andracki, J. Lafoon, S.K. Hunter, G.B. Schneider. J. Dent. Res. 84 (2005) 542-547.

114. Y.J. Ko, R.S. Zaharias, D.A. Seabold, J. Lafoon, G.B. Schneider. J. Prosthodont. 16 (2007) 431-438.

115. Y.S. Hwang, J. Cho, F. Tay, J.Y.Y. Heng, R. Ho, S.G. Kazarian, D.R. Williams, A.R. Boccaccini, J.M. Polak, A. Mantalaris. Biomaterials 30 (2009) 499-507.

116. G. Mazzoleni, F. Boukhechba, N. Steimberg, J. Boniotti, J.M. Bouler, N. Rochet. Proc. Eng. 10 (2011) 3662-3667.

117. N. Steimberg, J. Boniotti, G. Mazzoleni, In: Methods in Bioengineering: Alternative Technologies to Animal Testing, E. Novik, T. Maguire (Eds): Artech House publisher, USA, 2010, pp. 205-225.

118. A.S. Goldstein, T.M. Juarez, C.D. Helmke, M.C. Gustin, A.G. Mikos. Biomaterials 22 (2001) 1279-1288.

119. M. Hidaka, G.N. Su, J.K. Chen, K. Mukaisho, T. Hattori, G. Yamamoto. In Vitro Cell Dev. Biol. Anim. 43 (2007) 49-58.

120. K. Song, T. Liu, Z. Cui, X. Li, X. Ma. J. Biomed. Mater. Res. A 86 (2008) 323-332.

121. C. Kasper, K. Suck, F. Anton, T. Scheper, S. Kall, M. van Griensven, in Topics in Tissue Engineering, Vol. 3, N. Ashammakhi, R. Reis, E. Chiellini (Eds.), (C) 2007, pp. 1-15.

122. K. Suck, S. Roeker, S. Diederichs, F. Anton, J.A. Sanz-Herrera, I. Ochoa, M. Doblare, T. Scheper, M. van Griensven, C. Kasper. Biotechnol. Prog. 26 (2010) 671-678.

123. K.D. Ryder, R.L. Duncan. J. Bone Miner. Res. 16 (2001) 240-248.

124. H.L. Holtorf, J.A. Jansen, A.G. Mikos. J. Biomed. Mater. Res. A 72(2005) 326-334.

125. D. Du, T. Asaoka, T. Ushida, K.S. Furukawa. Biofabrication 6 (2014) 045002.

126. D. Du, K.S. Furukawa, T. Ushida. Biotechnol. Bioeng. 102 (2009) 1670-1678.

127. R.A. Perez, K. Riccardi, G. Altankov, M.P. Ginebra. J. Tissue Eng. 5 (2014) 2041731414543965.

128. T. Mygind, M. Stiehler, A. Baatrup, H. Li, X. Zou, A. Flyvbjerg, M. Kassem, C. Bünger. Biomaterials 28 (2007) 1036-1047.

129. S. Kedong, L. Wenfang, Z. Yanxia, W. Hong, Y. Ze, L. Mayasari, L. Tianqing. Appl. Biochem. Biotechnol. 174 (2014) 1331-1343.

130. H. Hosseinkhani, Y. Inatsugu, Y. Hiraoka, S. Inoue, Y. Tabata. Tissue Eng. 11 (2005) 1476-1488.

131. M. Jagodzinski, A. Breitbart, M. Wehmeier, E. Hesse, C. Haasper, C. Krettek, J. Zeichen, S. Hankemeier. J. Biomech. 41(2008) 1885-1891.

132. C. Liu, R. Abedian, R. Meister, C. Haasper, C. Hurschler, C. Krettek, G. von Lewinski, M. Jagodzinski. Biomaterials 33 (2012) 1052-1064.

133. A. Sittichockechaiwut, A.M. Scutt, A.J. Ryan, L.F. Bonewald, G.C. Reilly. Bone 44 (2009) 822-829.

134. A. Sittichokechaiwut, J.H. Edwards, A.M. Scutt, G.C. Reilly. Eur. Cell Mater. 20 (2010) 45-57.

135. O. Akhouayri, M.H. Lafage-Proust, A. Rattner, N. Laroche, A. Caillot-Augusseau, C. Alexandre, L. Vico. J. Cell Biochem. 76 (1999) 217-230. 
136. S. Barthelemi, J. Robinet, R. Garnotel, F. Antonicelli, E. Schittly, W. Hornebeck, S.J. Lorimier. Cell. Biochem. 113 (2012) 760-772.

137. J.R. Mauney, S. Sjostorm, J. Blumberg, R. Horan, J.P. O'Leary, G. Vunjak-Novakovic, V. Volloch, D.L. Kaplan. Calcif. Tissue Int. 74 (2004) 458-468.

138. N. Okii, S. Nishimura, K. Kurisu, Y. Takeshima, T. Uozumi. Neurol. Med. Chir. 41 (2001) 100-104.

139. C. Wu, Y. Ramaswamy, Y. Zhu, R. Zheng, R. Appleyard, A. Howard, H. Zreiqat. Biomaterials 30 (2009) 2199-2208.

140. B.D. Boyan, T.W. Hummert, D.D. Dean, Z. Schwartz. Biomaterials 17(1996) 137-146.

141. A. Ponche, M. Bigerelle, K. Anselme. Proc. Inst. Mech. Eng. H 224 (2010) 1471-1486.

142. K. Anselme, M. Bigerelle. Acta Biomater. 1 (2005) 211-222.

143. C. Michaels, J. Keller, C. Stanford, M. Solursh. J. Dent. Res. 68 (1989) 276-281.

144. K.T. Bowers, J.C. Keller, B.A. Randolph, D.G. Wick, C.M. Michaels. Int. J. Oral. Maxillofac. Implants 7 (1992) 302-310.

145. G. Kumar, C.K. Tison, K. Chatterjee, P.S. Pine, J.H. McDaniel, M.L. Salit, M.F. Young, C.G. Simon. Biomaterials 32(2011) 9188-9196.

146. I. Drosse, E. Volkmer, R. Capanna, P. De Biase, W. Mutschler, M. Schieker. Injury 39 (2008) S9-S20.

147. R.B. Rutherford, M. Moalli, R.T. Franceschi, D. Wang, K. Gu, P.H. Krebsbach. Tissue Eng 8 (2002) 441-452.

148. T.K. Sampath, J.C. Maliakal, P.V. Hauschka, W.K. Jones, H. Sasak, R.F. Tucker, K.H. White, J.E. Coughlin, M.M. Tucker, R.H. Pang, C. Corbett, E. Ozkaynak, H. Oppermann, D.C. Rueger. J. Biol. Chem. 267(1992) 20352-20362.

149. M. Dadsetan, T. Guda, M.B. Runge, D. Mijares, R.Z. LeGeros, J.P. LeGeros, D.T. Silliman, L. Lu, J.C. Wenke, P.R. Brown Baer, M.J. Yaszemski. Acta Biomater. 18 (2015) 9-20.

150. J. Zhang, H. Zhou, K. Yang, Y. Yuan, C. Liu. Biomaterials 34 (2013) 9381-9392.

151. Y. Yamada, M. Ueda, T. Naiki, M. Takahashi, K. Hata, T. Nagasaka. Tissue Eng. 10 (2004) 955-964.

152. G. Intini. Biomaterials 30 (2009) 4956-4966.

153. M.C. Durrieu, S. Pallu, F. Guillemot, R. Bareille, J. Amédée, C.H. Baquey, C. Labrugère, M. Dard. J. Mater. Sci. Mater. Med. 15 (2004) 779-786.

154. Y. Yamada, K. Hozumi, F. Katagiri, Y. Kikkawa, M. Nomizu. Biopolymers 94 (2010) 711-720.

155. Y. Yang, J.L. Magnay, L. Cooling, A.J. El Haj. Biomaterials 23(2002) 2119-2126.

156. M.A. Wood, S. Hughes, Y. Yang, A.J. El Haj. J. Control Rel. 112 (2006) 96-102.

157. M. Sriram, R. Sainitya, V. Kalyanaraman, S. Dhivya, N. Selvamurugan. Int. J. Biol. Macromol. 74 (2015) 404-412.

158. L. Wang, R.L. Carrier, Advances in Biomimetics, A. George (Ed.), InTech, 2011, Croatia. Available from: http://www.intechopen.com/books/advances-inbiomimetics/biomimetic-topography-bioinspired-cell-culture-substrates-andscaffolds.

159. P.G. Coelho, S.J. Hollister, C.L. Flanagan, P.R. Fernandes. Med. Eng. Phys. 37 (2015) 287-296.

160. L Cui, N Zhang, W Cui, P Zhang, X Chen. J. Bionic. Eng. 12 (2015) 117-128. 
161. C. Larsson, P. Thomsen, J. Lausmaa, M. Rodahl, B. Kasemo, L.E. Ericson. Biomaterials 15 (1994) 1062-1074.

162. M.J. Dalby, D. McCloy, M. Robertson, H. Agheli, D. Sutherland, S. Affrossman, R.O. Oreffo. Biomaterials 27 (2006) 2980-2987.

163. M.J. Dalby, N. Gadegaard, R. Tare, A. Andar, M.O. Riehle, P. Herzyk, C.D. Wilkinson, R.O. Oreffo. Nat. Mater. 6 (2007) 997-1003.

164. S. Song, E.J. Kim, C.S. Bahney, T. Miclau, R. Marcucio, S. Roy. Acta. Biomaterialia 18 (2015) 100-111.

165. J. Settleman. Mol. Cell. 14 (2004) 148-150.

166. M. Wieland, M. Textor, B. Chehroudi, D.M. Brunette. Biomaterials 26 (2005) 1119-1130.

167. O Zinger, G. Zhao, Z. Schwartz, J. Simpson, M. Wieland, D. Landolt, B. Boyan. Biomaterials 26 (2005) 1837-1847.

168. R. Olivares-Navarrete, P. Raz, G. Zhao, J. Chen, M. Wieland, D.L. Cochran, R.A. Chaudhri, A. Ornoy, B.D. Boyan, Z. Schwartz. Proc. Natl. Acad. Sci. USA 105 (2008) 15767-15772.

169. R. Olivares-Navarrete, S.L. Hyzy, R.A. 1st Gittens, J.M. Schneider, D.A. Haithcock, P.F. Ullrich, P.J. Slosar, Z. Schwartz, B.D. Boyan. Spine J. 13 (2013) 1563-1570.

170. D.W. Hamilton, K.S. Wong, D.M. Brunette. Calcif. Tissue Int. 78 (2006) 314-325.

171. D.W. Hamilton, D.M. Brunette. Biomaterials 28 (2007) 1806-1819.

172. A.J. Salgado, O.P. Coutinho, R.L. Reis. Macromol. Biosci. 4 (2004) 743-765.

173. K. Anselme, P. Linez, M. Bigerelle, D. LeMaguer, A. Le Maguer, P. Hardouin, H.F. Hildebrand, A. Iost, J.M. Leroy. Biomaterials 21 (2000B) 1567-1577.

174. D.D. Deligianni, N. Katsala, D. Sotiropoulou, J. Amedee, Y.F. Missirlis. Biomaterials 22 (2001) 1241-1251.

175. M.S. Sader, A. Balduino, A. Soares Gde, R. Borojevic. Clin. Oral Implants Res. 16 (2005) 667-675.

176. R. Olivares-Navarrete, S.L. Hyzy, D.L. Hutton, C.P. Erdman, M. Wieland, B.D. Boyan, Z. Schwartz. Biomaterials 31 (2010) 2728-2735.

177. J.Y. Martin, Z. Schwartz, T.W. Hummert, D.M. Schraub, J. Simpson, J. Lankford Jr, D.D. Dean, D.L. Cochran, B.D. Boyan. J. Biomed. Mater. Res. 29 (1995) 389-401.

178. J. Lincks, B.D. Boyan, C.R. Blanchard, C.H. Lohmann, Y. Liu, D.L. Cochran, D.D. Dean, Z. Schwartz. Biomaterials 19 (1998) 2219-2232.

179. R.A. Gittens, T. McLachlan, R. Olivares-Navarrete, Y. Cai, S. Berner, R. Tannenbaum, Z. Schwartz, K.H. Sandhage, B.D. Boyan. Biomaterials 32 (2011) 3395-3403.

180. S.S. Hakki, S.B. Bozkurt, E.E. Hakki, P. Korkusuz, N. Purali, N. Koç, M. Timucin, A. Ozturk, F. Korkusuz. Biomed. Mater. 7 (2012) 045006.

181. M. Lai, C.D. Hermann, A. Cheng, R. Olivares-Navarrete, R.A. Gittens, M.M. Bird, M. Walker, Y. Cai, K. Cai, K.H. Sandhage, Z. Schwartz, B.D. Boyan. J. Biomed. Mater. Res. A 103 (2015) 564-573.

182. K. Anselme, A. Ponche, M. Bigerelle. Proc. Inst. Mech. Eng. H 224 (2010) 1487-1507.

183. A.J. Salgado, M.E. Gomes, A. Chou, O.P. Coutinho, R.L. Reis, D.W. Hutmacher. Mater. Sci. Eng. C 20 (2002) 27-33.

184. A.C. MacIntosh, V.R. Kearns, A. Crawford, P.V. Hatton. J. Tissue Eng. Regen. Med. 2 (2008) 71-80. 
185. J.F.A. Valente, T.A.M. Valente, P. Alves, P. Ferreira, A. Silva, I.J. Correia. Mater. Sci. Eng. C Mater. Biol. Appl. 32 (2012) 2596-2603.

186. G.S. Lee, J.H. Park, J.E. Won, U.S. Shin, H.W. Kim. J. Mater. Sci. Mater. Med. 22 (2011) 1257-1268.

187. R.J. Kane, H.E. Weiss-Bilka, M.J. Meagher, Y. Liu, J.A. Gargac, G.L. Niebur, D.R. Wagner, R.K. Roeder. Acta Biomaterialia 17 (2015) 16-25.

188. S.W. Tsai, Y.H. Cheng, Y. Chang, H.L. Liu, W.B. Tsai. J. Taiwan Inst. Chem. Eng. (DNLM) 41 (2010) 247-251.

189. H. Kim, U. Kim, G. Leisk, C. Bayan, I. Georgakoudi, D. Kaplan. Macromol. Biosci. 7 (2007) 643-655.

190. H.J. Kim, U.J. Kim, G. Vunjak-Novakovic, B.H. Min, D.L. Kaplan. Biomaterials 26 (2005) 4442-4452.

191. H.J. Chung, T.G. Park. Adv. Drug Deliv. Rev. 59 (2007) 249-262.

192. C. Bertoldi, D. Zaffe, U. Consolo. Biomaterials 29 (2008) 1817-1823.

193. T. Jiang, W.I. Abdel-Fattah, C.T. Laurencin. Biomaterials 27 (2006) 4894-4903.

194. T. Jiang, Y. Khan, L.S. Nair, W.I. Abdel-Fattah, C.T. Laurencin. J. Biomed. Mater. Res. A 93 (2010) 1193-1208.

195. L.L. Smith, P.J. Niziolek, K.M. Haberstroh, E.A. Nauman, T.J. Webster. Int. J. Nanomedicine 2 (2007) 383-388.

196. M. Deng, L.S. Nair, S.P. Nukavarapu, S.G. Kumbar, T. Jiang, N.R. Krogman, A. Singh, H.R. Allcock, C.T. Laurencin. Biomaterials 29 (2008) 337-349.

197. N.R. Krogman, A.L. Weikel, K.A. Kristhart, S.P. Nukavarapu, M. Deng, L.S. Nair, C.T. Laurencin, H.R. Allcock. Biomaterials 30 (2009) 3035-3041.

198. D.W. Hutmacher. Biomaterials 21 (2000) 2529-2543.

199. H.H. Lu, S.F. El-Amin, K.D. Scott, C.T. Laurencin. J. Biomed. Mater. Res. A. 64 (2003) 465-474.

200. J.R. McConnell, B.J. Freeman, U.K. Debnath, M.P. Grevitt, H.G. Prince, J.K. Webb. Spine 28 (2003) 317-323.

201. F. Barrère, C.A. van Blitterswijk, K. de Groot. Int. J. Nanomedicine 1 (2006) 317-332.

202. G. Daculsi. Biomaterials 19 (1998) 1473-1478.

203. C. Ohtsuki, M. Kamitakahara, T. Miyazaki. J. R. Soc. Interface 6 (2009) S349-S360.

204. L. Cheng, F. Ye, R. Yang, X. Lu, Y. Shi, L. Li, H. Fan, H. Bu. Acta Biomater. 6 (2010) 1569-1574.

205. T.L. Arinzeh, T. Tran, J. Mcalary, G. Daculsi. Biomaterials 26 (2005) 3631-3638.

206. T.L. Arinzeh. Foot Ankle Clin. 10 (2005) 651-665.

207. J. Choy, C.E. Albers, K.A. Siebenrock, S. Dolder, W. Hofstetter, F.M. Klenke. Bone 69 (2014) 80-88.

208. B. Liu, P. Lin, Y. Shen, Y. Dong. J. Mater. Sci. Mater. Med. 19 (2008) 1203-1207.

209. J. Venugopal, S. Low, A.T. Choon, A.B. Kumar, S. Ramakrishna. Artif. Organs 32 (2008) 388-397.

210. M.V. Jose, V. Thomas, K.T. Johnson, D.R. Dean, E. Nyairo. Acta Biomater. 5 (2009) 305-315.

211. M. Ngiam, S. Liao, A.J. Patil, Z. Cheng, C.K. Chan, S. Ramakrishna. Bone 45 (2009) 4-16.

212. M.P. Prabhakaran, J. Venugopal, S. Ramakrishna. Acta Biomaterialia 5 (2009) 2884-2893. 
213. N. Rochet, T. Balaguer, F. Boukhechba, J.P. Laugier, D. Quincey, S. Goncalves, G.F. Carle. Biomaterials 30 (2009) 4260-4267.

214. E. Seyedjafari, M. Soleimani, N. Ghaemi, I. Shabani. Biomacromolecules 11 (2010) 3118-3125.

215. J. Zhao, W. Han, H. Chen, M. Tu, S. Huan, G. Miao, R. Zeng, H. Wu, Z. Cha, C. Zhou. J. Mater. Sci. Mater. Med. 23 (2012) 517-525.

216. C.C. Lin, S.J. Fu, Y.C. Lin, I.K. Yang, Y. Gu. Int. J. Biol. Macromol. 68 (2014) 39-47.

217. A.J. Ryan, J.P. Gleeson, A. Matsiko, E.M. Thompson, F.J. O'Brien. J. Anat. (2014) $1-14$.

218. D.L. Wheeler, L.G. Jenis, M.E. Kovach, J.M. Marini, A.S. Turner. Spine J. 7 (2007) 308-317.

219. T. Gao, H.T. Aro, H. Ylanen, E. Vuorio. Biomaterials 22 (2001) 1475-1483.

220. J.R. Jones, S. Lin, S. Yue, P.D. Lee, J.V. Hanna, M.E. Smith, R.J. Newport. Proc. Inst. Mech. Eng. H 224(2010) 1373-1387.

221. H. Oonishi, L.L. Hench, J. Wilson, F. Sugihara, E. Tsuji, M. Matsuura, S. Kin, T. Yamamoto, S. Mizokawa J. Biomed. Mater. Res. 51 (2000) 37-46.

222. M. Peltola, I. Kinnunen, K. Aitasalo. J. Oral Maxillofac. Surg. 66 (2008) 639-646.

223. P.M. Crapo, T.W. Gilbert, S.F. Badylak. Biomaterials 32 (2011) 3233-3243.

224. T.W. Gilbert. J. Cell Biochem. 113 (2012) 2217-2222.

225. G.I. Drosos, K.I. Kazakos, P. Kouzoumpasis, D.A. Verettas. Injury 38 (2007) S13-S21.

226. J.J. Song, H.C. Ott. Trends Mol. Med. 17 (2011) 424-432.

227. I.G. Kim, M.P. Hwang, P. Du, J. Ko, C. W. Ha, S. H. Do, K. Park. Biomaterials 50 (2015) 75-86.

228. T.J. Cho, L.C. Gerstenfeld, T.A. Einhorn. J. Bone Miner. Res. 17 (2001) 513-520.

229. T.N. Vo, F.K. Kasper, A.G. Mikos. Adv. Drug Deliv. Rev. 64 (2012) 1292-1309.

230. K. Tsukii, N. Shima, S. Mochizuki, K. Yamaguchi, M. Kinosaki, K. Yano, O. Shibata, N. Udagawa, H. Yasuda, T. Suda, K. Higashio. Biochem. Biophys. Res. Commun. 246(1998) 337-341.

231. R.F. Lai, Z.J. Li, Z.Y. Zhou, Z.Q. Feng, Q.T. Zhao. Pac. J. Trop. Med. 6 (2013) 884-888.

232. L. Prodanov, J. te Riet, E. Lamers, M. Domanski, R. Luttge, J.J. van Loon, J.A. Jansen, X.F. Walboomers. Biomaterials 31 (2010) 7758-7765.

233. T.J. Webster, C. Ergun, R.H. Doremus, R.W. Siegel, R. Bizios. J. Biomed. Mater. Res. 51 (2000) 475-483.

234. T.J. Webster, C. Ergun, R.H. Doremus, R.W. Siegel, R. Bizios. Biomaterials 21 (2000) 1803-1810.

235. E. Lamers, X.F. Walboomers, M. Domanski, J. te Riet, F.C. van Delft, R. Luttge, L.A. Winnubst, H.J. Gardeniers, J.A. Jansen. Biomaterials 31 (2010) 3307-3316.

236. H. Yoshimoto, Y.M. Shin, H. Terai, J.P. Vacanti. Biomaterials 24 (2003) 2077-2082.

237. B. Zhao, H. Hu, S.K. Mandal, R.C. Haddon. Chem. Mater. 17 (2005) 3235-3241.

238. D. Khang, J. Lu, C. Yao, K.M. Haberstroh, T.J. Webster. Biomaterials 29 (2008) 970-983.

239. R.L. Price, M.C. Waid, K.M. Haberstroh, T.J. Webster. Biomaterials 24 (2003) 1877-1887.

240. K.L. Elias, R.L. Price, T.J. Webster. Biomaterials 23 (2002) 3279-3287.

241. X. Liu, J. Y. Lim, H.J. Donahue, R. Dhurjati, A.M. Mastro, E.A. Vogler. Biomaterials 28 (2007) 4535-4550. 
242. A.S. Badami, M.R. Kreke, M.S. Thompson, J.S. Riffle, A.S. Goldstein. Biomaterials 27 (2006) 596-606.

243. J.K. Wise, A.L. Yarin, C.M. Megaridis, M. Cho. Tissue Eng. Part A 15 (2009) 913-921.

244. H.R. Ramay, M. Zhang. Biomaterials 21 (2004) 171-180.

245. J. Venugopal, P. Vadgama, T.S. Sampath Kumar, S. Ramakrishna. Nanotechnology 18 (2007) 1-8.

246. M. Gibson, V. Beachley, J. Coburn, P.A. Bandinelli, H.Q. Mao, J. Elisseeff. Biomed. Res. Int. 2014 (2014) 469120.

247. C. Li, C. Vepari, H.J. Jin, H.J. Kim, D.L. Kaplan. Biomaterials 27 (2006) 3115-3124.

248. Z. Shi, X. Huang, Y. Cai, R. Tang, D. Yang. Acta Biomater. 5 (2009) 338-345.

249. G. Balasundaram, M. Sato, T.J. Webster. Biomaterials 27 (2006) 2798-2805.

250. S.B. Gayathri, P. Kamaraj. Nano Vision 1(2011) 1-13.

251. H. Zhou, J. Lee. Acta Biomaterialia 7 (2011) 2769-2781.

252. K.A. Beningo, M. Dembo, Y.L. Wang. Proc. Natl. Acad. Sci. USA 101 (2004) 18024-18029.

253. D.S.W. Benoit, A.R. Durney, K.S. Anseth. Tissue Eng. 12 (2006) 1663-1673.

254. A. Gantar, L.P. da Silva, J.M. Oliveira, A.P. Marques, V.M. Correlo, S. Novak, R.L. Reis. Mater. Sci. Eng. C Mater. Biol. Appl. 43 (2014) 27-36.

255. V.V.D. Rani, L. Vinoth-Kumar, V.C. Anitha, K. Manzoor, M. Deepthy, V.N. Shantikumar. Acta Biomaterialia 8 (2012) 1976-1989.

256. Z. Wang, and Q. Hu. Biomed. Mater. 5 (2010) 045007.

257. G. Tomoaia, O. Soritau, M. Tomoaia-Cotisel, L.-B. Pop, A. Pop, A. Mocanu, O. Horovitz, L.-D. Bobos. Powder Technol. 238 (2013) 99-107.

258. M. Bhattacharya, S. Chaudry. Mater. Sci. Eng. C Mater. Biol. Appl. C 33 (2013) 2601-2610.

259. B. Marelli, C.E. Ghezzi, D. Mohn, W.J. Stark, J.E. Barralet, A.R. Boccaccini, S.N. Nazhat. Biomaterials 32 (2011) 8915-8926.

260. Q. Lv, M. Deng, B.D. Ulery, L.S. Nair, C.T. Laurencin. Clin. Orthop. Relat. Res. 471 (2013) 2422-2433.

261. I.A. Siqueira, M.A. Corat, B.D. Cavalcanti, W.A. Neto, A.A. Martin, R.E. Bretas, F.R. Marciano, A.O. Lobo. ACS Appl. Mater. Interfaces (2015) [Epub ahead of print]. 